\title{
EVALUATING THE IMPACT OF OPERATING ENERGY REDUCTION MEASURES ON EMBODIED ENERGY
}

\author{
A Thesis \\ by \\ VARUSHA VENKATRAJ \\ Submitted to the Office of Graduate and Professional Studies of \\ Texas A\&M University \\ in partial fulfillment of the requirements for the degree of \\ MASTER OF SCIENCE
}

Chair of Committee, Manish Dixit

Committee Members, Wei Yan

Sarel Lavy

Head of Department, Patrick Suermann

May 2019

Major Subject: Construction Management

Copyright 2019 Varusha Venkatraj 


\begin{abstract}
Buildings are known to consume around $48 \%$ of the world's annual energy in their construction, operation and maintenance causing significant damage to the environment due to the resultant carbon emissions. During their lifecycle, buildings consume energy in the form of embodied energy (EE) and operating energy (OE). In a conventional building, EE accounts for 10-20\% of a buildings lifecycle energy (LCE), while OE accounts for 80$90 \%$. As a result, the building sector has taken several measures to reduce OE consumption in buildings. These OE reducing measures fail to account for the subsequent increase in EE, and might result in increasing the overall building's LCE. A systematic review of literature shows that, there is limited research that comprehensively evaluates the impact of $\mathrm{OE}$ reduction measures on $\mathrm{EE}$ for different construction assemblies. Therefore, making the design decision process extremely tedious and complex. This study has created a knowledge base that would inform energy optimization decision-making during the building's lifecycle. For this, LCE consumption is calculated and evaluated on ASHRAE's 90.1-2016, benchmark model for each OE reducing measure across different commercial building envelope construction assemblies. In future, this knowledge will allow building designers to take an informed step towards reducing overall energy consumption in buildings.
\end{abstract}




\section{ACKNOWLEDGEMENTS}

I would like to thank my committee chair, Dr. Manish Dixit, and my committee members, Dr. Yan, Dr. Lavy for their support and guidance during the course of my research.

I would also like to thank Dr. Caffey, Dr. Lewis, and Liz Smith for their encouragement and motivation during my time here at Texas A\&M University. 


\section{CONTRIBUTORS AND FUNDING SOURCES}

\section{Contributors}

This work was supervised by a thesis committee consisting of Dr. Dixit (committee chair), and Dr. Lavy from the construction science department and Dr.Yan from the architecture department. All the work was independently carried out by myself.

\section{Funding Sources}

This work did not receive any funding from the department or other sources. 
NOMENCLATURE

$\begin{array}{ll}\text { EE } & \text { Embodied Energy } \\ \text { OE } & \text { Operating Energy } \\ \text { LCE } & \text { Lifecycle Energy } \\ \text { LCEA } & \text { Lifecycle Energy Analysis } \\ \text { BIM } & \text { Building Information Modelling } \\ \text { IEE } & \text { Initial Embodied Energy } \\ \text { REE } & \text { Recurrent Embodied Energy } \\ \text { DE } & \text { Demolition Energy } \\ \text { GBS } & \text { Green Building Studio } \\ \text { O and M } & \text { Operation and Maintenance } \\ \text { EUI } & \text { Energy Use Intensity } \\ \text { WWR } & \text { Window to Wall ratio }\end{array}$




\section{TABLE OF CONTENTS}

Page

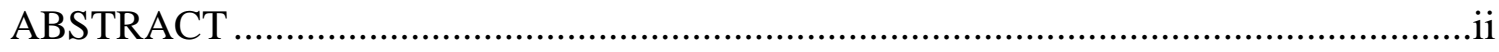

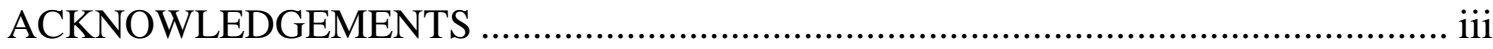

CONTRIBUTORS AND FUNDING SOURCES ......................................................

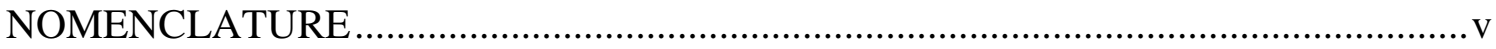

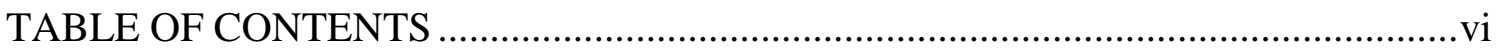

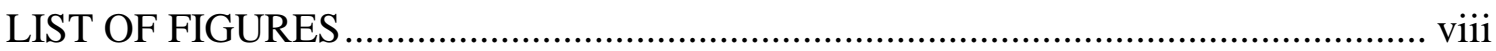

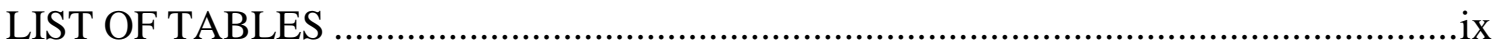

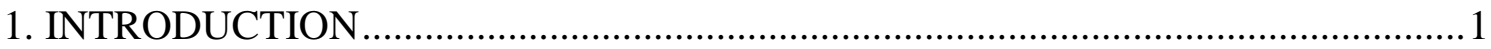

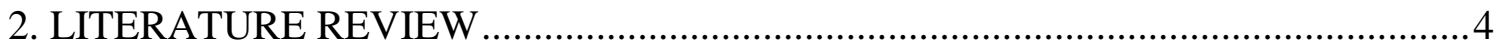

2.1. Understanding building lifecycle energy and its components ............................ 4

2.1.1. Embodied energy (EE) ..................................................................... 4

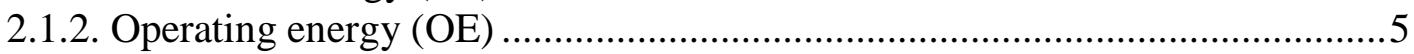

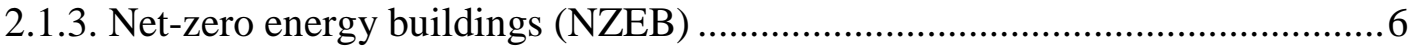

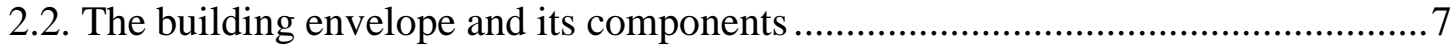

2.2.1. Heat gain through the building envelope ........................................... 8

2.2.2. Components of the building envelope ....................................................... 9

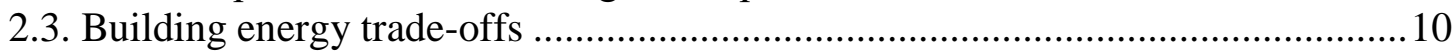

2.3.1. Impact of added insulation on building LCE ............................................. 12

2.3.2. Impact of changing window to wall ratio (WWR) on building LCE ............. 14

2.3.3. Impact of changing amount of solar shading devices on LCE....................... 17

2.4. Studies on embodied and operating energy trade-offs .................................... 19

2.5. Tools used for building lifecycle energy analysis .........................................20

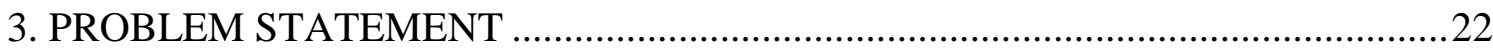

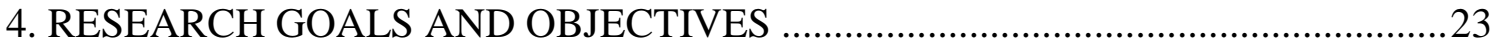

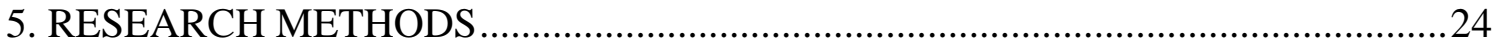

6. RESULTS 


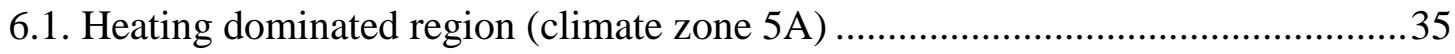

6.2. Cooling dominated region (climate zone 2A) ............................................... 45

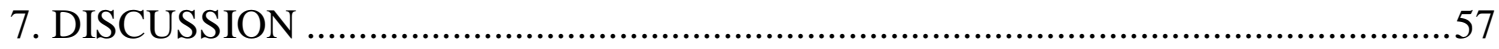

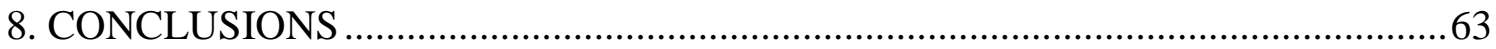

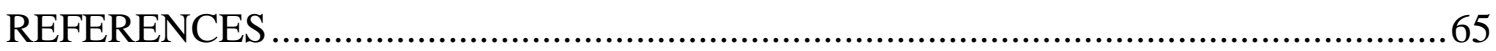

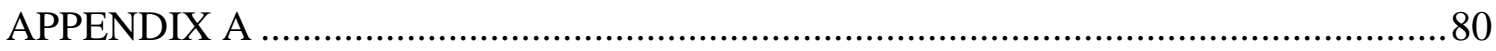

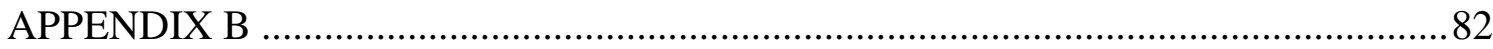




\section{LIST OF FIGURES}

Page

Figure 1 WWR interdependencies of building energy components ............................ 17

Figure 2 EE variation caused by applying OE reduction measures on Assembly 1b ......36

Figure 3 EE variation caused by applying OE reduction measures on Assembly $2 \mathrm{~b}$.......38

Figure 4 EE variation caused by applying OE reduction measures on Assembly $3 b$......40

Figure 5 EE variation caused by applying OE reduction measures on Assembly 4b ......42

Figure 6 OE vs EE evaluation for the most optimized model across different wall

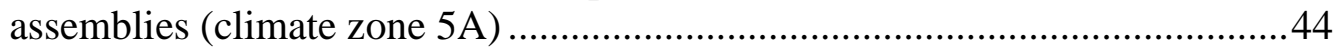

Figure $7 \mathrm{OE}$ trade-offs for wall assembly $1 \mathrm{~b}$ (climate zone 5A) ...............................45

Figure 8 EE variation caused by applying OE reduction measures on Assembly 1a ......47

Figure 9 EE variation caused by applying OE reduction measures on Assembly 2a ......49

Figure 10 EE variation caused by applying OE reduction measures on Assembly $3 \mathrm{a}$....51

Figure $11 \mathrm{EE}$ variation caused by applying OE reduction measures on Assembly $4 \mathrm{a}$....53

Figure $12 \mathrm{OE}$ vs EE evaluation for the most optimized model across different wall assemblies (climate zone 2A) ................................................................55

Figure 13 OE trade-offs for wall assembly 1a (climate zone 2A) ...............................56

Figure 14 e-Quest vs GBS, variation in EUI, for wall assembly 1 a ............................61

Figure 15 e-Quest vs GBS, variation in EUI, for wall assembly $4 \mathrm{a} \ldots \ldots \ldots \ldots \ldots \ldots \ldots \ldots \ldots \ldots . . .61$ 


\section{LIST OF TABLES}

Page

Table 1 Measure taken to reduce operating energy by corresponding study

Table 2 Common material used in commercial construction

Table 3 Details of ASHRAE 90.1-2016, benchmark model

Table 4 Summary of OE and EE variation, along with EE factor for wall assembly $1 b$, in a heating dominated region.

Table 5 Summary of OE and EE variation, along with EE factor for wall assembly $2 b$,

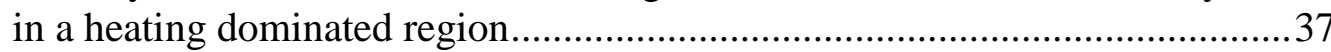

Table 6 Summary of OE and EE variation, along with EE factor for wall assembly 3b,

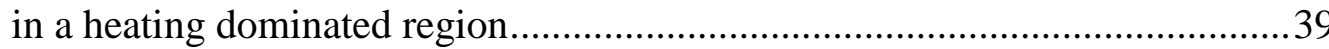

Table 7 Summary of OE and EE variation, along with EE factor for wall assembly $4 \mathrm{~b}$, in a heating dominated region....

Table 8 Summary of OE and EE variation, along with EE factor for wall assembly 1a, in a heating dominated region............................................................. 46

Table 9 Summary of OE and EE variation, along with EE factor for wall assembly 2a, in a heating dominated region.

Table 10 Summary of $\mathrm{OE}$ and EE variation, along with EE factor for wall assembly $3 \mathrm{a}$, in a heating dominated region

Table 11 Summary of OE and EE variation, along with EE factor for wall assembly $4 \mathrm{a}$, in a heating dominated region. 


\section{INTRODUCTION}

Today's world is facing several environmental concerns such as climate change, ozone layer depletion, energy crisis, global warming, waste accumulation, rapid urbanization etc., (Lim et al., 2018; Cabeza et al., 2014). Current research shows that the building industry consumes around $48 \%$ of the world's energy annually, making it a major contributor of greenhouse emissions (Dixit, 2017). This is because buildings consume energy during their entire lifecycle i.e. construction, operation, maintenance, renovation and demolition (Dixit, 2017; Cabeza et al., 2014; Ibn-Mohammed et al., 2013). The increase in global energy consumption, emphasizes upon the need to improve the energyefficiency of a building to meet the required demand (Bakar et al., 2015). As a result, several studies have looked into active and passive measures to achieve energy-efficient building designs (Lim et al., 2018). In addition, multiple building energy assessment tools have been developed over the last few years to inform designers regarding the energy consumption of a building and optimize their designs (Hernandez and Kenny, 2011). These tools generate several design options and evaluate them based on their energy consumption (Wang et al., 2005). With these tools generating several design options, and the involvement of multiple design variables - the design decision making process for an energy-efficient building becomes an extremely complex process (Lim et al., 2018).

Most recently, the building industry has shifted its focus towards net-zero energy buildings (NZEB), carbon neutral buildings, and even net-positive buildings (Lutzkendorf et al., 2014). Although, these high-performance buildings consume minimal energy for 
their operation they are associated with high embodied energy (EE) consumption (Hernandez and Kenny, 2011; Ramesh et al., 2010). This is due to the fact that these buildings often employ additional material, technology or systems to decrease the energy demand during their use-phase (Lim et al., 2018; Cabeza et al., 2014; Hernandez and Kenny, 2011). Therefore, making it particularly critical to assess embodied energy (EE) impacts as we approach NZEB or carbon neutral buildings. However, literature shows that numerous studies fail to assess building energy from a lifecycle perspective. Generally, these studies tend to concentrate upon reducing the OE consumption of a building (Zuo et al., 2017). Moreover, most of these building energy assessment tools are extremely disjointed, making it difficult to simultaneously assess operating energy (OE) and embodied energy (EE) requirements in a building (Lim et al., 2018). As a result, designers do not have sufficient information regarding building lifecycle energy evaluation methods or the practical guidance to perform holistic lifecycle energy analysis (Lutzkendorf et al., 2014). Nevertheless, to achieve overall reduction in building energy, it is important to reduce both operating and embodied energy.

In this study, we have created a comprehensive knowledge base that evaluates the EE implications by various OE reduction strategies for different building envelope construction assemblies. The study is focused upon comparing OE and EE results for various design options in two different climate zones (heating dominated and cooling dominated) for a building lifespan of 60 years. The findings from this study provides useful information regarding building energy trade-offs that would help building design decision makers identify appropriate energy conservation measures from a building 
lifecycle perspective. Furthermore, this study can be extended to evaluate other sustainability indicators such as global warming potential, acidification potential, eutrophication potential, human toxicity etc. In the future, this study would help in developing tools and technologies that evaluate building energy trade-offs thereby enabling overall lifecycle energy reduction. 


\section{LITERATURE REVIEW}

\subsection{Understanding building lifecycle energy and its components}

The building's life cycle energy (LCE) consists of the following components: embodied energy (EE), and operating energy (OE) (Cabeza et al., 2014). Building lifecycle energy assessment (LCEA) is the process of quantifying and evaluating the energy flows in a building system (Ramesh et al., 2010). LCEA, helps in evaluating the environmental performance of the various products and processes used in construction over their entire lifecycle. This includes extracting the raw material, manufacturing the products, transporting these products on-site, using, disposing and recycling them. Therefore, the LCEA is also considered as a "cradle to grave" approach of evaluating environmental impacts (Cabeza et al., 2014). The application of LCEA, has gained significant popularity over the last two decades, due to its holistic approach of evaluating building energy at more than one lifecycle phase and also acknowledging interactions between different lifecycle phases (Zuo et al., 2017).

\subsubsection{Embodied energy (EE)}

The EE of a building includes the sum of the energy embodied in the building material (extraction, manufacturing and transportation) and the building construction energy (Dixit, 2017; Copiello, 2016; Shrivastava and Chini, 2012). According to Dixit (2017) the EE of a building consists of three major components: initial embodied energy (IEE), recurrent embodied energy (REE), and demolition energy (DE). The IEE will 
include the sum of all the direct (e.g. construction and transportation) and indirect (mining, transporting and transforming construction material) energy requirements related to the construction of the building (Dixit, 2017; Copiello, 2016). Energy embodied in building materials constitute a major portion of EE in buildings (Praseeda et al., 2016). Therefore, appropriate material selection plays a crucial role in reducing EE of buildings. Using materials with high EE such as brick, glass, cement aluminum, steel etc., results in increasing the EE of a building (Praseeda et al., 2016). The REE includes the energy required to replace or refurbish certain materials that are used in the building since the lifetime of the material is lesser than the building's service life (Ramesh et al., 2010). The REE expenditure mostly occurs during the operations and maintenance $(\mathrm{O}$ and $\mathrm{M})$ phase of a building's lifecycle (Dixit, 2017). The DE, is the energy consumed during the end of a building's service life to demolish and dispose the various building components (Dixit, 2017; Ramesh et al., 2010).

\subsubsection{Operating energy (OE)}

The $\mathrm{OE}$ refers to the energy spent on operating and maintaining $(\mathrm{O}$ and $\mathrm{M})$ the building. This includes heating, ventilation and air-conditioning (HVAC) loads, lighting loads and plug loads (Karimpour et al., 2014; Sartori et al., 2012; Thormark, 2002). The components of space conditioning and lighting requirements are predominantly dependent upon the location of the building (climate zone), and the occupant's comfort. Generally, building located in extreme climatic zones, consume higher $\mathrm{OE}$ to meet their heating and cooling requirements (Praseeda et al., 2016). Several studies show that a more than half 
of the building's LCE is consumed during $\mathrm{O}$ and $\mathrm{M}$ phase in the form of OE (80-90\%). This is followed by the embodied energy (10-20\%), while the demolition energy has a negligible share (Zeng and Chini, 2017; Chastas et al., 2016; Karimpour et al., 2013; Ramesh et al., 2010).

Since OE consumes most of the building's energy, lot of attention has been given to this aspect of building design to decrease $\mathrm{OE}$ demand. This need to reduce the $\mathrm{OE}$ demand in buildings, has led to the use of energy-intensive material (in terms of their production process) (Copiello, 2016). For example, a study conducted by Lu et al. (2015) increased the insulation thickness of the exterior walls to reduce OE consumption. However, there was no discussion regarding the subsequent increase in EE. This issue becomes significant as we approach energy efficient buildings, carbon-neutral buildings or net-zero energy buildings (NZEB).

\subsubsection{Net-zero energy buildings (NZEB)}

The concept of a NZEB, is based upon an innovative approach to mitigate OE consumption in a building (Praseeda et al., 2016; Kapsalaki et al., 2012). A NZEB, needs to maintain a zero-energy balance annually. To elaborate further, NZEB's produce energy onsite using renewable sources of energy such as photovoltaic panels. These panels produce energy that is required for the building operation and its occupants over a oneyear period (Lutzkendorf et al., 2014). In certain scenarios, there is a need for NZEB's to borrow energy from the electric grid. However, they are equipped with systems that 
generate energy which can then be exported into the electric grid to ensure that the annual energy-balance is zero (Kapsalaki et al., 2012). An energy efficient building, regulates and controls the amount of energy consumed while maintaining a thermally comfortable ambience for its occupants (Bakar et al., 2015). To minimize their energy needs, these buildings use several energy-efficient measures that adopt new technology and renewable sources of energy (Bakar et al., 2015. Very often these energy efficient measures significantly increase EE, sometimes even contributing towards nearly $98 \%$ of the total building energy. Upon comparing the building LCE between NZEB and conventional buildings, the LCE consumption in NZEB are higher due to the increased EE demand.

\subsection{The building envelope and its components}

The indoor and outdoor environments are separated by the building envelope. The thermal performance of the building envelope is a crucial factor that controls the quality of the indoor ambient conditions and ensures occupant comfort. The building envelope consists of several components such as - walls, fenestrations (windows and doors), roofs, foundations, thermal insulation, thermal mass, shading devices etc., (Sadineni et al., 2011). A building's thermal envelope can be designed in a number of ways to reduce operating energy (Gustavsson et al., 2010). 


\subsubsection{Heat gain through the building envelope}

The study conducted by Pacheco et al. (2012), shows that the thermal performance of a building envelope, influences nearly $75 \%$ of a building's OE loads. Generally, heat gain in building envelopes occur due to conduction, convection and radiation (Lam et al., 2005). In a building envelope, conduction occurs through the opaque envelope assemblies (U-value), convection occurs due to natural or pressure-driven air movements and radiation occurs due to solar heat gain from openings (Lam et al., 2005). Building envelopes have varying requirements based on the needs of a specific geographical location (Li et al., 2013). Generally, limiting the amount of summer heat gain and winter heat loss through the building envelope improves its thermal performance (Li et al., 2016). The key factors that influence the thermal performance of a building envelope are orientation, exterior wall area and construction type (thermal insulation and U-value), surface finish, glazing type and size of windows (wall to window ratio), exterior shading devices, and roof area and its construction (Lam et al., 2005).

Several studies show that decisions that are made earlier in the design process have more potential to reduce overall building LCE (Basbagill et al., 2013; Pacheco et al., 2012). According to Li et al. (2013), the most common measures used to achieve energy efficiency in the built environment can be divided into three categories: (i) External heat transfer (building envelope), (ii) Internal heat gain (people, lighting, plug loads, etc.,), and

(iii) Building system services (mechanical systems, elevators). Amongst these three categories, the building envelope has the most impact on the overall building energy (Pacheco et al., 2012). 


\subsubsection{Components of the building envelope}

Building orientation: Aligning the major axis of the building after carefully considering the relationship of the building, with its physical surroundings and the sun path - during the design stages will significantly help in lowering the end-use energy consumption (Morrisey et al., 2011). Choosing the best orientation for a building, is considered the most effective passive design strategy for saving energy (Pacheco et al., 2012). A correctly oriented building, requires lesser heating and cooling when compared with other buildings, because of lesser solar heat gain. In addition, these buildings will be able to capture maximum light and reduce the internal loads due to artificial lighting (Pacheco et al., 2012). From an energy perspective, the orientation of a building controls the (i) amount of daylight entering the building, and (ii) heat gain/loss through the building envelope (Morrisey et al., 2011). As a general rule of thumb, the longer wall sections are oriented to the south (Pacheco et al., 2012).

Walls: The amount of thermal insulation used in the exterior walls, significantly controls the amount of conductive heat gain/loss through the building envelope. (Li et al, 2013). The selection criteria of thermal insulation are heavily dependent upon the thermal conductivity and thermal inertia of the material. The low thermal conductance or high thermal resistance in these materials slows the rate of heat flow into or out of a building (Sadineni et al., 2011). Applying optimum insulation thickness in the building helps in drastically reducing HVAC loads. Commonly used insulation materials include mineral wool, fiberglass batts, extruded polystyrene, expanded polystyrene, polyurethane etc. 
However, these materials have high embodied impact due to their large ozone layer depleting potential and global warming potential.

Roofs: The roof of a building constitutes an important component of the building envelope, that is extremely prone to heat gain. This mainly occurs due to their entire surface area being exposed to solar radiation and environmental change for long durations of time (Sadineni et al., 2011). The roofs, massively influence the indoor occupancy comfort level and the overall thermal performance of a building. In recent times, a huge variety of roofing options have been developed to suit our needs. Some roofing options include masonry roofs, lightweight roofs, ventilated and micro-ventilated roofs, cool roofs and green roofs.

\subsection{Building energy trade-offs}

There are several studies related to building lifecycle energy. Most of these studies focus upon the operational energy consumption in buildings and measures to reduce $\mathrm{OE}$, while very few of them address the EE aspect (Praseeda et al., 2016). This is because 83\% of a buildings LCE consumption is concentrated upon its operational phase (Scheuer et al., 2003). In addition, most of these studies ignore/neglect the EE aspect of building energy consumption because of the following reasons: (i) inconsistent or inaccurate $\mathrm{EE}$ data, (ii) limited number of tools to evaluate EE, and (iii) no direct benefits related to building construction costs (Wang et al., 2005). However, it is important to understand that the implementation of $\mathrm{OE}$ reduction measures is usually associated with high IEE 
consumption (Zhang et al., 2016; Ramesh et al., 2010). For example, several studies suggest providing higher insulation on the exterior walls are roofs, using multiple pane windows with coatings (low-emissivity), changing the window to wall ratio (WWR) or employing additional shading devices (Cabeza et al., 2014). These energy conservation measures help in dramatically reducing building OE (Peippo et al., 1999). However, in most cases, the IEE payback time of these energy-efficient measures are much longer than the buildings lifecycle; this causes detrimental impacts on the environment and results in being counter-productive to our objective of reducing energy consumption (Chastas et al., 2016; Cabeza et al., 2014; Ramesh et al., 2010).

Several studies also show that measures that are applied to reduce certain $\mathrm{OE}$ components might have a negative impact on the remaining OE components. For example, minimizing the energy used for heating might have a negative implication on the energy required for cooling or artificial lighting (Goia, 2016). Another study conducted by Yohanis and Norton (2002) found that the IEE of a building could be around $67 \%$ of its OE for a 25-year period. Nonetheless, the energy spent to construct a building verses the energy spent on operating the building creates a paradox (Copiello, 2016). Therefore, overall building energy reduction must carefully address trade-offs between both operating and embodied energy components (Treloar, 1997). 


\subsubsection{Impact of added insulation on building LCE}

Literature consists of numerous studies that suggest using additional insulation in a building as an OE reduction measure. Rodrigues and Freire (2017) conducted a comprehensive analysis of using alternative insulation thicknesses (no insulation, $40 \mathrm{~mm}$, $80 \mathrm{~mm}$, and $120 \mathrm{~mm}$ of expanded polystyrene) to identify the most optimum solution. The case study was conducted on a single-family house and an apartment complex that were located in Coimbra, Portugal. Both the EE and OE impacts were assessed for a period of 50 years. The EE impacts of the single-family house and apartments were found to account for $26-57 \%$ and $25-49 \%$ of the total LCE respectively. The overall energy reduction that was achieved by using thicker insulation was lesser than $3 \%$. The results of their study also showed that increasing the insulation thickness to $120 \mathrm{~mm}$ had embodied impacts that were greater than operational impacts. In conclusion, the study observed that adding extra insulation beyond a certain tipping point can result in higher EE impacts, without significant reduction in $\mathrm{OE}$.

Fay et al. (2000) conducted a study to determine the impacts of increasing insulation on the overall building energy consumption. The study uses an Australian based, two-storey residential building as a case study to demonstrate these impacts. The base scenario has exterior walls that have $50 \mathrm{~mm}$ thick fiberglass insulation. It was observed that the base scenario had an EE of $35.4 \mathrm{MJ} / \mathrm{m}^{2}, \mathrm{OE}$ of $300 \mathrm{MJ} / \mathrm{m}^{2}$ and LCE of 140.4 MJ $/ \mathrm{m}^{2}$ A study case with higher insulation was created as a variation from the base case. The insulation was increased from the base case to R-2.5 bulk insulation in the walls, R-1 insulation in the roofs and R-4 insulation in the ceilings. For a building lifespan of 
100 years, it was found that for the base case with added insulation, the EE was 36.5 $\mathrm{MJ} / \mathrm{m}^{2}$, OE was $210 \mathrm{MJ} / \mathrm{m}^{2}$ and LCE was $132.5 \mathrm{MJ} / \mathrm{m}^{2}$. It was found that the overall netlifecycle saving due to the use of additional insulation was less than $6 \%$. Therefore, implying that other strategies might need to be considered before increasing the insulation in a building.

Mithraratne and Vale (2004) conducted a LCEA on a timber-framed house located in New Zealand. Additional layers of insulation were added to the timber-frame house as an energy saving measure. Upon comparing LCE for a period of 100 years, it was observed that the base case with $94 \mathrm{~mm}$ thick fiberglass insulation had an EE of $4425 \mathrm{MJ} / \mathrm{m}^{2}$, space heating requirement of $7736.4 \mathrm{MJ} /$ annum and LCE of $17017 \mathrm{MJ} / \mathrm{m}^{2}$. The second, more insulated version of the building used $25 \mathrm{~mm}$ polystyrene as insulation. This version of the building had its EE increased to $4764 \mathrm{MJ} / \mathrm{m}^{2}$, while the space heating requirement decreased to $7048.6 \mathrm{MJ} / \mathrm{annum}$. Interestingly, the total building LCE decreased to 16237 $\mathrm{MJ} / \mathrm{m}^{2}$. The third super insulated version, doubled the insulation used in the base case. In this case, the EE increased to $5041 \mathrm{MJ} / \mathrm{m}^{2}$ while the space heating and LCE requirement decreased to $4172.4 \mathrm{MJ} / \mathrm{annum} 11832 \mathrm{MJ} / \mathrm{m}^{2}$ respectively.

Sartori and Hestnes (2007) conducted a case study on six versions of a building (one conventional, four low energy and one self-sufficient) to evaluate their LCE demand. Here, it was observed that the self-sufficient version of the building consumed more energy than certain low-energy versions. This can be attributed to the high embodied energy, that was required in order to integrate the energy saving measures into the self- 
sufficient version. Several other studies suggest using a thicker layer of insulation to lower the consumption of OE. However, the high IEE consumption might take a long time to payback and sometimes might take longer than the building lifespan.

The study conducted by Crawford and Treloar (2005) shows that the EE consumed by a building is usually no more that $15 \%$ of the total energy use of a building for a 50 year lifespan. However, in a well-insulated energy efficient building; the EE can account towards $40 \%$ of the total energy consumption therefore even exceeding OE. Therefore, most often the excessive use of active and passive technologies to reduce OE, might become counter-productive. In these cases, it becomes important to quantify the extent until which $\mathrm{OE}$ can be reduced, before the EE starts increasing significantly; thereby increasing the overall LCE during its lifetime (Ramesh et al., 2010).

Design improvements made to the building envelope to improve thermal efficiency are usually associated with higher material production energy intensity and construction burden (Balouktsi and Lutzkendorf, 2016; Chastas et al., 2016). While material changes might cause a significant decrease in OE consumption, they lead to insignificant savings in terms of building LCE. In certain cases, they can even result in higher building LCE due to increase in EE (Crawford et al., 2016).

\subsubsection{Impact of changing window to wall ratio (WWR) on building LCE}

Thermal and visual comfort in a built environment is achieved through airconditioning and artificial lighting respectively (Li et al., 2005). Recent studies show that 
air-conditioning accounts for $40-60 \%$ of electricity use, while lighting accounts for 20 30\% (Li et al., 2005). Both these loads have a direct relationship with the thermal performance of the building envelope. The building envelope is a simple combination of transparent (windows) and opaque surfaces. The ratio between the transparent and opaque surfaces have a major impact on the energy balance (with implications on heating and cooling loads), and daylight availability (with implications on artificial lighting loads) in a building (Goia, 2016; Peippo et al., 1999).

The overall thermal transfer value (OTTV) of a building envelope is controlled by two factors, they are (i) solar heat gain and (ii) WWR (Li et al., 2005). More recently, there has been a trend of incorporating daylighting into the building design. Exploiting the availability of natural light has the tremendous potential of reducing artificial lighting loads (Goia, 2016; Alghoul et al., 2015). Having a large WWR causes higher heat conduction through the glass windows and lower heat conduction through the opaque walls and vice-versa ( $\mathrm{Li}$ et al., 2005). This results in increasing the solar heat gain in a building- contributing towards increased space cooling requirements. While several studies claim that this increased cooling load can be offset by the daylight induced savings it is also important to understand that these savings might vary based on the temperature and climate of a specific region (Kalogirou and Bojic, 2000; Yin et al., 2011). The study performed by Yohanis and Norton (2002) found that having a WWR of 15\%has the lowest OE demand. In hot regions, majority of the cooling loads occur due to heat gain through windows. Therefore, increasing the WWR becomes detrimental, since it contributes towards approximately $40-50 \%$ of the total heating load in winter, and $20-30 \%$ of the 
cooling loads in summers (Yin et al., 2011). On the other hand, the consequence of reducing the WWR is less natural light, thereby resulting in an increase of lighting loads (Utama and Gheewala, 2009).

In addition, to conflicting impacts on OE components, the WWR is also associated with EE implications. This implies that careful material and component selection with appropriate thermal and optical properties is necessary to reduce heating, cooling and lighting loads (Goia, 2016). According to the studies conducted by Utama and Gheewala (2009) and Yohanis and Nortan (2002) it was found that reducing the WWR did not consume additional EE. This may be attributed to the reduction of the windows (amount of glass) and window frame (timber) quantities. This reduction was sufficient to adjust the additional EE for the material in the wall construction (brick). However, in certain cases, the EE associated with a particular wall assembly is much higher than that of glass. Here, the EE shows a significant increase with decrease in WWR. However, the results of the study performed by Giordano et al. (2015) were contradictory to the study performed by Utama and Gheewala (2009). The study by Giordano et al. (2015) found that increasing the WWR increased the EE for different wall construction assemblies. This was mainly due to the high IEE associated with glass and aluminum products, that are used in windows. Therefore, carefully addressing the conflicting impacts of different LCE components becomes an important step in improving the performance of a building ( $\mathrm{Li}$ et al., 2005). 


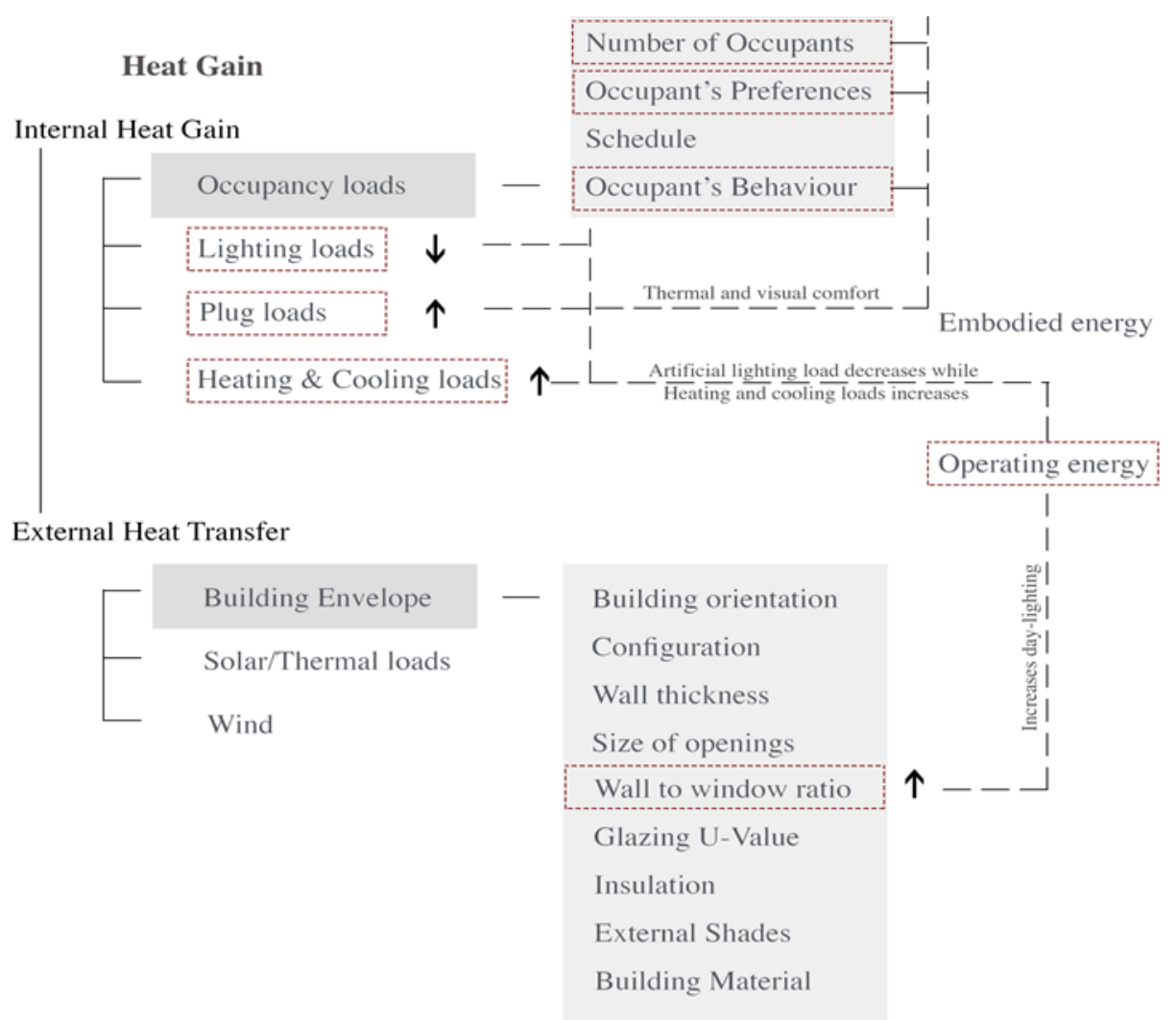

Figure 1 WWR interdependencies of building energy components

\subsubsection{Impact of changing amount of solar shading devices on LCE}

Solar shading devices are overhangs that are used to protect the transparent surface of a building envelope from solar radiation by blocking the unwanted energy flow into a building (Bellia et al., 2013). These devices increase the efficiency of the façade by helping us dynamically control the solar heat gain and daylight that enters the building (Goia, 2016). Shading devices have different implications on the heating, cooling and lighting loads of a building ( $\mathrm{Li}$ et al., 2016). Literature shows that the use of external shading is the most effective in reducing building loads amongst several other passive energy-reducing strategies ( $\mathrm{Li}$ et al., 2016). Nearly $80 \%$ of the solar heat gain can be 
reduced by shading all the fenestrations in a building; this accounts to $8 \%$ of the building cooling loads (Bellia et al., 2013; Ebrahimpour and Maerefat, 2011). A major fraction of a building's thermal load is due to solar heat gain, in hot climatic regions; thereby making external shading devices extremely useful in these regions (Pacheco et al., 2012). The choice of shading device depends upon the size of the window (influences overhang depth), orientation of the building and the apparent sun path (Bellia et al., 2013). Overhangs on the southern façade and louvres on the east-west façade help in achieving optimal results. While solar shading helps in reducing cooling energy demand, it leads to an increase in energy demands for both heating and lighting systems. This is because shading devices block solar heat radiation and the entry of natural light into the building; thereby increasing our heating loads in the winters and lighting loads (Bellia et al., 2013; Pacheco et al., 2012).

Adding additional shading structures generally require additional labor, and materials that are associated with higher embodied energy (Huang et al., 2012). The $\mathrm{CO}_{2}$ emissions payback period, has a negative effect when shading systems are implemented. For example, in the study conducted by Huang et al. (2012) it was found that 440 tons of building materials was utilized to cover a window glazing area of approximately $1838 \mathrm{~m}^{2}$. This additional need for building materials lead to high amounts of energy investments and $\mathrm{CO}_{2}$ emissions. Furthermore, shade depths are determined by the window heights (Pacheco et al., 2012). Therefore, larger windows require more material for providing optimum levels of shading. Understanding the balance between external shades on 
heating, cooling, lighting and EE demands is important for overall building energy reduction.

\subsection{Studies on embodied and operating energy trade-offs}

Utama and Gheewala (2009) conducted a study to evaluate the EE impact of using single vs double wall for a high-rise residential building in Jakarta, Indonesia. They performed a building LCEA, to ascertain the impact of using different building envelope construction assemblies on the building's HVAC loads. The double walls constituted of clay bricks, gypsum plaster board and an air gap in between, while the single wall comprised of clay bricks. The EE of the building was calculated using process-based method, while the $\mathrm{OE}$ was computed using Ecotect. It was found that the EE of the double wall envelope was $79500 \mathrm{MJ}$ and that for single wall envelope was $74.5 \mathrm{MJ}$. The OE consumption for the double wall envelope was $194000 \mathrm{MJ}$ and single walls envelope was 383700 GJ. The overall LCE of the building was 282900 GJ for the double walls and $460000 \mathrm{MJ}$ for the single walls. Thereby, implying that even though the EE was higher for the double wall system, the overall LCE was much lesser.

Crawford et al. (2010) calculated the LCE requirements for eight residential construction assemblies over a 50-year period. The system boundary in this study included the IEE, REE, DEE and the OE of the building. An input-output model, using the Australian energy database was used to calculate EE, while the $\mathrm{OE}$ was calculated using the TRNSYS software. Here, different material that were used in each assembly was 
applied to a 'box' that had an area of $50 \mathrm{~m}^{2}$ with $3 \mathrm{~m}$ high walls. Subsequently, three different sized boxes were subjected to a sensitivity analysis. The results of this analysis showed that the difference in the space conditioning loads of these boxes. In conclusion, the study determined that using an assembly that has high IEE, might improve the thermal performance of the assembly and lessen material replacement, consequently reducing the LCE of a building.

Certain studies have made recommendations, to enhance the existing methods used to perform building LCEA, which are relatable to our study. For example, the study by Basbagill et al. (2013) emphasizes upon the vitality of making effective design decision during the initial conceptual stages. The building information modeling (BIM) tools are used to inform designers regarding the energy consumption of a particular building material. In this manner, BIM enabled decision making helps designers identify the combination of materials that helps in reducing the environmental impact. Shrivastava and Chini (2012) performed a similar study to identify the impacts of IEE upon material selection with the help of BIM tools to improve LCEA related decision making.

\subsection{Tools used for building lifecycle energy analysis}

Input data for most of the tools used in LCA calculations include the building geometry and orientation, ventilation and air-tightness, building envelope characteristics, shading devices, building system services and human factors (Santos et al., 2014). Climate data is usually obtained from the International Weather Energy Calculation 
database (Santos et al., 2014). In most cases, Energy Plus (simulation tool), is used to calculate the OE of a building. This tool was developed upon the DOE-2 platform and has the same accuracy as DOE-2 (Coakley et al., 2014; Wilde et al., 2010). However, the input files of these simulation tools are not very well integrated with existing BIM tools, thereby limiting their use during early design stages (Basbagill et al., 2013). To resolve this issue, Autodesk developed plug-in Green Building Studio (GBS) which is used to perform energy simulations within the BIM interface. In doing so, the BIM software does not need to communicate with another software, thereby eliminating the issue of interoperability. In addition, Abanda and Byers (2016) conducted a study to verify the accuracy of results obtained from GBS with another simulation tool (Ecotect). The outcome from both these tools were similar with very insignificant variations. 


\section{PROBLEM STATEMENT}

Several studies have investigated the lifecycle energy requirements of buildings. Most of these studies typically address the implications of OE reduction measures on EE, on an aggregated building level. In addition, a limited number of studies explore the effect of using different construction assemblies on EE. According to literature, there is a lack of studies that evaluates EE impacts caused due to both - OE reduction measure and construction assembly type. Therefore, quantifying the individual influence of each $\mathrm{OE}$

reducing measure across different construction assemblies on EE is still required (Crawford et al., 2016; Ajayi et al., 2015; Ibn-Mohammed et al., 2013). 


\section{RESEARCH GOALS AND OBJECTIVES}

A building that is considered to be carbon neutral or zero energy during its operational phase is usually constructed using energy-intensive material that has high EE impacts (Ajayi et al., 2015). Therefore, the goal of this study is to enable holistic building lifecycle analysis that informs energy optimization decision making. This goal will be achieved through the following research objectives:

- Quantify and compare trade-offs on EE demand, caused by OE reduction measures for different building assembly types. This will be achieved by performing an energy simulation on ASHRAE's 90.1-2016 benchmark building in a heating and cooling dominated region.

- Compute EE use (EE-factor) per unit of OE saving for different OE reduction measures across construction assemblies. 


\section{RESEARCH METHODS}

This study was conducted in four steps:

(i) Conducting a rigorous review of related literature: A systematic review of literature was performed to identify $\mathrm{OE}$ reduction measures and commonly used building assembly types in commercial buildings. The Google scholar database was used as our primary electronic source of information. In addition, resources from the Texas A \& M university library such as the ASHRAE standard 90.1-2016, was also reviewed to gather related information. The search in Google scholar was performed using keywords such as building lifecycle energy, operating energy, embodied energy, building envelope, construction assemblies, net-zero energy buildings, building information modelling, energy simulation tools, etc., to create a sample of published studies that were most relevant to our study. This initial search resulted in finding over 4500 studies in the form of journal papers, conference proceedings, government documents, material specification reports, industry research reports, Ph.D. dissertations etc., from the year 1997 to 2018.

After an initial screening of these studies, some of them were excluded from the review due to a mismatch of the main points being reviewed in this paper, lack of details and failure to comprehensively address the concept of reducing building LCE. This failure to understand the definition of building LCE can be observed in several studies, since they have not holistically included the evaluation of $\mathrm{EE}, \mathrm{OE}$, and other forms of renewable energy in their LCEA calculations (Hernandaz and Kenny, 2010). 
As a result, our search was narrowed down to only include studies based on our inclusion criteria. Eventually, this search resulted in finding 109 studies, that were crucial in providing us with a comprehensive understanding of the topic. The common measures used to reduce operating energy by changing building envelope parameters, that were identified in literature are shown in Table 1. It was found that these measures need to be carefully selected, to improve the thermal performance of the building envelope and reduce $\mathrm{OE}$ consumption. The gathered information was then organized in the form of a matrix (as seen in Table 1) with the name of the study listed on the Y-axis and the corresponding OE reduction measure listed on the X-axis. Furthermore, details regarding various $\mathrm{OE}$ reducing building materials and their construction assemblies were also collected as a part of the literature review.

Table 1 Measure taken to reduce operating energy by corresponding study

\begin{tabular}{|c|c|c|c|c|c|c|c|c|c|c|c|c|}
\hline \multirow[t]{3}{*}{ Study } & \multicolumn{12}{|c|}{ Building Component } \\
\hline & \multicolumn{7}{|c|}{ Walls } & \multicolumn{3}{|c|}{ Windows } & \multicolumn{2}{|c|}{ Roofs } \\
\hline & 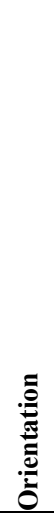 & 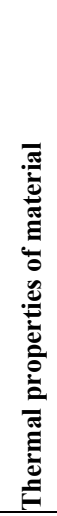 & 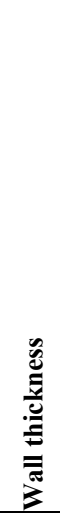 & 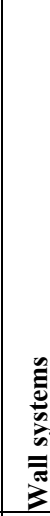 & 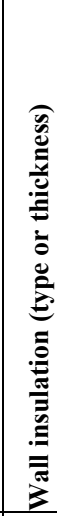 & 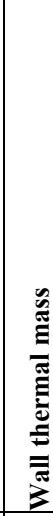 & 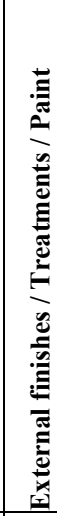 & $\begin{array}{l}0 \\
0 \\
0 \\
0\end{array}$ & 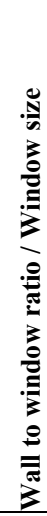 & 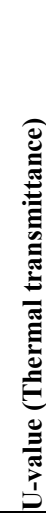 & 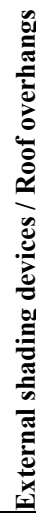 & 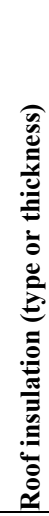 \\
\hline Harkouss et al., & & & * & & 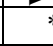 & & & $*$ & 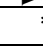 & & & $=$ \\
\hline Chastas et al., 2016 & * & & & & 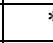 & & 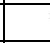 & * & & st & & \\
\hline Lau et al., 2016 & & & & & & & & * & & & & \\
\hline Zhao et al., 2016 & * & & & & 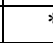 & & & $*$ & & 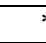 & & \\
\hline Zhu et al., 2013 & & & & 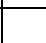 & & & & $*$ & & & & * \\
\hline
\end{tabular}


Table 1 Continued

\begin{tabular}{|c|c|c|c|c|c|c|c|c|c|c|c|c|}
\hline \multirow[t]{3}{*}{ Study } & \multicolumn{12}{|c|}{ Building Component } \\
\hline & \multicolumn{7}{|c|}{ Walls } & \multicolumn{3}{|c|}{ Windows } & \multicolumn{2}{|c|}{ Roofs } \\
\hline & 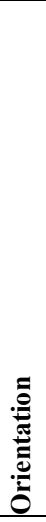 & 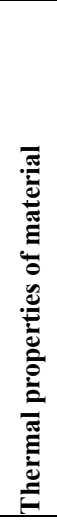 & 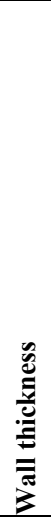 & 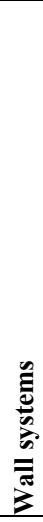 & 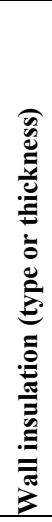 & 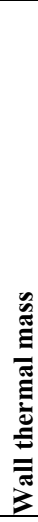 & 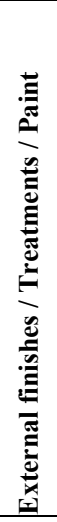 & $\begin{array}{l}0 \\
0 \\
0 \\
0 \\
0\end{array}$ & 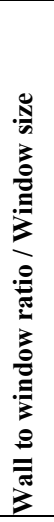 & 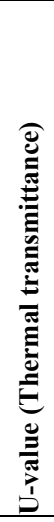 & 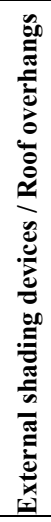 & 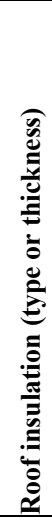 \\
\hline \multicolumn{13}{|l|}{ Stevanovic, 2013} \\
\hline Susorova et al., 2013 & $*$ & & & & & & & & $*$ & & & \\
\hline Pacheco et al., 2012 & $*$ & & & & $*$ & & & $*$ & $*$ & $*$ & & \\
\hline Kaynakli, 2012 & & & & & $*$ & & & & & & & \\
\hline Attia et al., 2012 & $*$ & & $*$ & & $*$ & & & $*$ & $*$ & & $*$ & * \\
\hline Asadi et al., 2012 & & & & * & $*$ & & & $*$ & & & & \\
\hline Chesne et al., 2012 & & & & & $*$ & & & & & & & \\
\hline Zinzi et al., 2012 & & & & & & & $*$ & & & & & \\
\hline Ramesh et al., 2012 & & & $*$ & * & $*$ & & & & & $*$ & & * \\
\hline Shi, 2011 & & & & & $*$ & & & & & & & \\
\hline Sadineni et al., 2011 & & $*$ & & * & $*$ & trat & $*$ & $*$ & & & $*$ & * \\
\hline Al-Tamimi et al., 2011 & & & & & & & & & & & $*$ & \\
\hline Jelle, 2011 & & & & * & $*$ & & & & & $*$ & & \\
\hline Shameri et al., 2011 & & & & & & & & $*$ & $*$ & & $*$ & \\
\hline Zamella et al., 2011 & & & & & & & & $*$ & $*$ & & $*$ & \\
\hline Gasparella et al., 2011 & $*$ & & & & & & & $*$ & $*$ & & $*$ & \\
\hline Leskovar and Premrov, & $*$ & & & & & & & $*$ & $*$ & $*$ & & \\
\hline Jaber and Ajib, 2011 & $*$ & & & & & & & $*$ & $*$ & & & \\
\hline Sozer, 2010 & $*$ & & & & $*$ & & & $*$ & $*$ & & $*$ & \\
\hline Castleton et al., 2010 & & & & & & & & & & $*$ & & * \\
\hline Hassouneh et al., 2010 & $*$ & & & & & & & $*$ & $*$ & & & \\
\hline Aste et al., 2010 & & & & & $*$ & 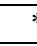 & & & & & & \\
\hline Singh and Garg, 2009 & & $*$ & & & & & & $*$ & & $*$ & & \\
\hline Utama and Gheewala, & & $*$ & $*$ & * & & & & & & $*$ & & \\
\hline Ochoa and Capeluto, & $*$ & & & & & & & $*$ & $*$ & $*$ & $*$ & \\
\hline Bahaj et al., 2008 & & & & & & & & $*$ & & & & \\
\hline Yu et al., 2008 & & & & & $*$ & & & $*$ & $*$ & & $*$ & \\
\hline Masoso and Grobler, & & & & & $*$ & & & & & & & \\
\hline Poirazis et al., 2008 & & & & & & & & $*$ & $*$ & & & \\
\hline Xing et al., 2008 & & $*$ & & * & & & & & & $*$ & & \\
\hline Li and Wong, 2007 & & & & & & & & & & & $*$ & \\
\hline Wang et al., 2007 & & & & & & & & & $*$ & $*$ & $*$ & \\
\hline Chitherlet and Defaux, & & & & & $*$ & & & & & & & \\
\hline Lollini et al., 2006 & & & & & $*$ & & & & & & & $*$ \\
\hline Persson et al., 2006 & $*$ & & & & & & & $*$ & $*$ & & & \\
\hline Marceau and VanGeem, & & & & * & & & & & & & & \\
\hline Wang et al., 2005 & $*$ & & & * & & & & $*$ & $*$ & & $*$ & \\
\hline
\end{tabular}


Table 1 Continued

\begin{tabular}{|c|c|c|c|c|c|c|c|c|c|c|c|c|}
\hline \multirow[t]{3}{*}{ Study } & \multicolumn{12}{|c|}{ Building Component } \\
\hline & \multicolumn{7}{|c|}{ Walls } & \multicolumn{3}{|c|}{ Windows } & \multicolumn{2}{|c|}{ Roofs } \\
\hline & 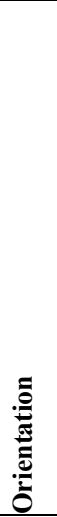 & 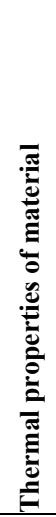 & 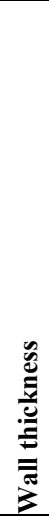 & 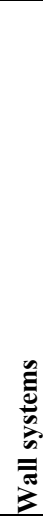 & 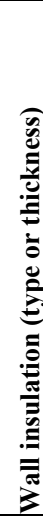 & 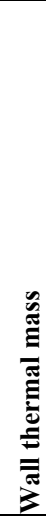 & 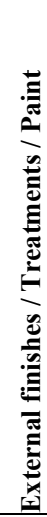 & $\begin{array}{l}0 \\
0 \\
0 \\
0 \\
0\end{array}$ & 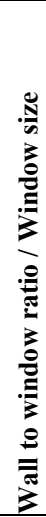 & 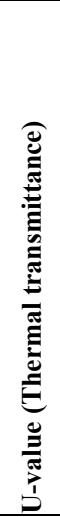 & 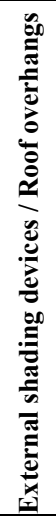 & 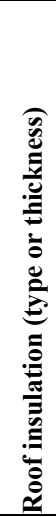 \\
\hline Christenen et al., 2005 & $*$ & & & & & * & & * & * & * & $*$ & \\
\hline Cheung et al., 2005 & & & & & 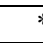 & * & * & * & * & & * & \\
\hline Mitraratne and Vale, & & & & & 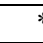 & & & & & & & \\
\hline Oral et al., 2004 & & & * & & 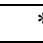 & & & * & * & * & & \\
\hline Caldas and Norford, & & & & * & & & & & * & & & \\
\hline Comakli and Yuksel, & & & & & 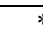 & & & & & & & \\
\hline Bojic et al., 2002 & & & & & t; & & & & & & & \\
\hline Scofield, 2002 & * & & * & & 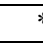 & 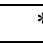 & & * & * & * & * & \\
\hline Oral and Yilmaz, 2002 & * & & & & & & & * & * & * & & \\
\hline Balaras et al., 2000 & & & & & 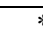 & & 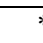 & * & & & $*$ & \\
\hline Bouchlaghem, 2000 & * & * & * & & t & & 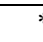 & * & * & & * & \\
\hline Chan and Chow, 1998 & & & & & 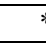 & & & & 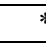 & * & * & \\
\hline
\end{tabular}

In addition, the literature review also helped us identify common materials that were used for enhancing the performance of the building, as shown in Table 2. The materials were divided into three categories, they are walls, windows, and roofs. Several material options that were found in literature are listed below these categories. This material list helped us create various wall and roof assemblies for our study (Table 2).

Table 2 Common material used in commercial construction

\begin{tabular}{|l|l|}
\hline \multicolumn{1}{|c|}{ Building System } & \multicolumn{1}{c|}{ Material Options } \\
\hline \multicolumn{2}{|c|}{ Walls } \\
\hline Structural system & Steel stud framing (cold formed metal) \\
\hline & Concrete masonry units \\
\hline Sheathing & Gypsum sheathing, 1/2" exterior grade \\
\hline Drywall & Gypsum board \\
\hline
\end{tabular}


Table 2 Continued

\begin{tabular}{|c|c|}
\hline Building System & Material Options \\
\hline \multicolumn{2}{|c|}{ Walls } \\
\hline \multirow[t]{6}{*}{ Insulation } & Expanded polystyrene \\
\hline & Extruded polystyrene \\
\hline & Fiber glass \\
\hline & Mineral wool \\
\hline & Cellulose \\
\hline & Rigid foam \\
\hline \multirow[t]{5}{*}{ Exterior finishes } & Brick Veneer, 4" \\
\hline & Concrete panels, 2" \\
\hline & Stone Veneer, 2" (limestone) \\
\hline & Pre-cast metal panels \\
\hline & Paint \\
\hline \multicolumn{2}{|c|}{ Windows } \\
\hline \multirow[t]{2}{*}{ Window or door frames } & Aluminum \\
\hline & Fiber glass \\
\hline \multirow[t]{6}{*}{ Window glazing } & Double glazed \\
\hline & Gas filled (Argon filled) \\
\hline & Vacuum glazed \\
\hline & Aerosol gels \\
\hline & Low- e coated \\
\hline & Reflective coating \\
\hline \multicolumn{2}{|c|}{ Roofs } \\
\hline Structural Systems & Concrete, supported by steel joists and deck \\
\hline \multirow[t]{4}{*}{ Exterior finish } & Asphalt shingles \\
\hline & Cement flooring tiles \\
\hline & Composite shingles \\
\hline & Clay tile or Modified bitumen \\
\hline \multirow[t]{3}{*}{ Roof insulation } & 4" EPDM insulation \\
\hline & Extruded polystyrene \\
\hline & Polyurethane \\
\hline \multicolumn{2}{|c|}{ Floors } \\
\hline Flooring systems & 4" concrete slab \\
\hline \multirow[t]{4}{*}{ Floor finish } & Carpet \\
\hline & Tile, vinyl tile \\
\hline & Cement finished floors \\
\hline & Terrazzo \\
\hline
\end{tabular}

(ii) Developing the Benchmark model: To quantify and compare the building lifecycle energy associated with different construction assemblies, we created a benchmark model based on ASHRAE 90.1, 2016 standards using a BIM enhanced approach. The benchmark model was created using Autodesk Revit as the BIM authoring tool. The benchmark model is a two-floor educational building of approximately 210,900 
$\mathrm{ft}^{2}$. Table 3, gives us a detailed description of the benchmark model. In this study, we consider the ASHRAE 90.1-2016 benchmark model to be a stand-alone building without considering its surrounding environment. The system boundary in the study considers only heating, cooling and lighting loads as OE.

Table 3 Details of ASHRAE 90.1-2016, benchmark model

\begin{tabular}{|c|c|}
\hline Building component & Description \\
\hline Building Form & \\
\hline Window height and location & 4'6" continuous band \\
\hline Shading devices & None \\
\hline Floor to Floor height & $13^{\prime}$ \\
\hline Floor construction & 6" concrete slab +carpet finish \\
\hline Exterior wall construction & $\begin{array}{l}\text { Steel framed walls }(2 \times 4,16 \text { IN OC) } \\
\text { Stucco + Insulation + Gypsum sheathing }\end{array}$ \\
\hline Roof construction & $\begin{array}{l}\text { Built up roof } \\
\text { Roof finish }+ \text { Insulation }+ \text { Metal deck }\end{array}$ \\
\hline Skylights & 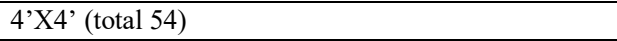 \\
\hline
\end{tabular}

(iii) Applying OE reduction measures to the benchmark model: After creating the benchmark model, we modelled eight variations of construction assemblies for the external wall. For each construction assembly, we would apply an OE reducing measure identified in literature to calculate overall building LCE. The commonly identified categories of $\mathrm{OE}$ reduction measures that were identified in literature include (i) building orientation, (ii) window glazing type, (iii) window shading, (iv) window-wall ratio, and (v) assembly of the roof construction. Parameters belonging to each category were then varied and their subsequent impact on the $\mathrm{OE}$ and $\mathrm{EE}$ of the building was recorded. The 
study covers 60 years of the building lifecycle, located in two different climate zones in the United States. Therefore, the building's energy performance is evaluated in a (i) heating dominated region (Chicago, Illinois), and, (ii) cooling dominated region (Houston, Texas), for each measure across different construction assemblies. These climate zones were specifically chosen based on the degree-days concept. The heating and cooling degree days (HDDs and CDDs) are used as a measure to determine the severity of winter and summer conditions in a geographic location. These HDDs and CDDs of a region, directly impact the energy requirement in a building (Li et al., 2013). According to the ASHRAE 90.1, 2016 standards the climates for Chicago and Houston are classified into climate zones 5A cold-humid climate and 2A hot-humid climate respectively. Therefore, the difference in the number of HDDs and CDDs between Houston and Chicago will help us study the variation in the results for different climate zones.

Autodesk Revit Green Building Studio (GBS) is used to compute the building's OE requirements while Autodesk Tally is used to compute the EE requirements. Both these tools, are plug-ins that are integrated with Autodesk Revit. However, when the energy settings of the benchmark model were exported from Autodesk Revit and imported into GBS there were some inaccuracies in the construction details of the envelope assemblies. To resolve this issue, pre-defined constructions with the desired U-values were selected from the GBS interface to run the energy simulations and obtain the results. The default weather files available on GBS, for the specified locations were used to run the simulations. Furthermore, simulations were also performed on two exterior wall assemblies using E-quest to verify the results obtained from GBS. 
(iv) Interpreting data obtained from the energy simulations: The difference in $\mathrm{EE}$ for each OE reduction measure, helped us develop an evaluation criterion that would give us information regarding the most effective $\mathrm{OE}$ reduction measure to the least effective measure, for a specific construction assembly. Appendix A, shows us a list of materials that will be used in a combination, to create construction assemblies for the purpose of this study. The R-values for the hot-humid climate of Houston, range from R-13 to R-27, while the R-values for the cold-humid climate of Chicago vary from R-19 to R-30. 


\section{RESULTS}

As The results generated from this study can be categorized into (i) heating dominated region (climate zone 5A), and (ii) cooling dominated region (climate zone 2A). The categories have further sub-categories for four different construction assemblies. Each of these assemblies are then analyzed based upon their (i) orientation, (ii) glazing system, (iii) shading, (iv) WWR, and (v) roof construction. These energy simulations were conducted to collect data regarding the trade-offs between the various $\mathrm{OE}$ and $\mathrm{EE}$ components on an annual basis.

The ASHRAE 90.1-2016 baseline benchmark model was simulated based on real measurements and construction assemblies that were specified in their prescriptive codes for climate zone 2A and 5A (Table 5.5-2 and Table 5.5-5 of ASHRAE standard 90.12016). According to the Normative Appendix G of ASHRAE standard 90.1-2016, the baseline energy consumption for the benchmark model is calculated by averaging the results obtained by rotating the entire building to 90,180 and 270 degrees and its actual orientation. Tables 4-11, show the results for the annual energy use intensity (EUI) and total embodied energy in $\mathrm{kBtu}$ per $\mathrm{ft}^{2}$ per year, for study cases with different $\mathrm{OE}$ reduction measure applied across varying construction assemblies.

The orientation of the building, is the first study case category that was analyzed. The building was rotated in increments of $45^{\circ}$ to cover all the eight quadrants. According to the ASHRAE standard 90.1-2016, the $45^{\circ}$ angle is the smallest rotational increment, 
that would have a noticeable influence on the EUI of a building. These increments are sufficient to analyze the sensitivity of a building to its orientation. The positive values denote a clockwise rotation, while the negative values denote a counter-clockwise rotational angle. Secondly, the impact of various glazing systems on the overall building energy was analyzed. The different glazing systems used in this study were low-e glazing, insulated reflective low-e glazing, double-pane low-e glazing and triple-pane low-e glazing. Thirdly, the impact of external shading on the overall building loads was calculated. The window shades were modelled with depths of 9 in (1/6 window height), 13.5 in (1/4 window height) 18 in (1/3 window height), 27 in (1/2 window height), and 36 in (2/3 window height). Fourthly, the impact of changing the WWR was on the final building loads was studied. The WWR was varied with values of $15 \%, 30 \%, 40 \%$ and $50 \%$. Finally, the impact of varying the level of insulation in the roof assembly on the overall building load was calculated. The insulation in the roof had different materials such as extruded polystyrene insulation, expanded polystyrene insulation, rigid foam insulation and polyurethane board insulation. The R-value of the roof was varied between R-30 and R-45 and the subsequent impacts on OE and EE was simulated.

As predicted earlier, the EUI of all the simulated study cases is much lesser than that of the baseline, except when the WWR is between 40-50\%. This confirms that all of the $\mathrm{OE}$ reduction measures are helpful in reducing building loads. Later, the operating and embodied energy demand of the baseline benchmark model was compared with the alternative construction assemblies to generate the gradient diagram. For Figures 2-5 and $7-10$, the $\mathrm{X}$-axis of this diagram represents the percentage of OE or EE that is added or 
reduced when compared with ASHRAE's 90.1-2016 benchmark model, while, the Y-axis is representative of each $\mathrm{OE}$ reducing measure that was applied to the model. The $\mathrm{X}$-axis of these figures use upper-case captions to denote major categories, while using lowercase captions for their sub-categories. These figures would help us understand the relationship between conflicting energy reducing measures.

The percentage of OE and EE difference is calculated by comparing the energy demand in the study case to the ASHRAE 90.1-2016 benchmark model. The \% of OE difference is calculated using Equation 1,

change $(\Delta)=\mathrm{EUI}$ of study case $-\mathrm{EUI}$ of ASHRAE 90.1-2016 baseline
$\%$ of OE difference $=($ change $/$ EUI of ASHRAE 90.1-2016 baseline) $\times 100 \quad$ (Equation 1)
While, the \% of EE difference is calculated using Equation 2,
change $(\Delta)=\mathrm{EE}_{\text {of study case }-\mathrm{EE}_{\text {of ASHRAE 90.1-2016 baseline }}}$
$\%$ of EE difference $=($ change / $\mathrm{EE}$ of ASHRAE 90.1-2016 baseline) $\times 100 \quad$ (Equation 2)

The $\%$ decrease is represented using negative numbers, while the $\%$ increase is represented as positive values. The EE factor is calculated as the amount of EE spent per $\mathrm{kBtu}$ of $\mathrm{OE}$ saved. This value is obtained by dividing the $\mathrm{EE}$ with $\mathrm{OE}$ (as seen in Tables 4-11). 


\subsection{Heating dominated region (climate zone $5 \mathrm{~A}$ )}

As seen in Table 4, the ASHRAE 90.1-2016 benchmark model has a total EUI of $80.43 \mathrm{kBtu} / \mathrm{ft}^{2} /$ year and embodied energy consumption of $8.15 \mathrm{kBtu} / \mathrm{ft}^{2} / \mathrm{year}$.

Table 4 Summary of OE and EE variation, along with EE factor for wall assembly $1 \mathrm{~b}$, in a heating dominated region

\begin{tabular}{|c|c|c|c|c|c|}
\hline \multirow{4}{*}{$\begin{array}{l}\text { MEASURES FOR OE } \\
\text { REDUCTION }\end{array}$} & \multicolumn{5}{|c|}{ ASSEMBLY $1 \mathrm{~b}(\mathrm{U}=0.04)$} \\
\hline & \multirow{2}{*}{$\begin{array}{c}\text { OPERATING } \\
\text { ENERGY } \\
\text { EUI }\end{array}$} & \multirow{2}{*}{$\begin{array}{c}\text { EMBODIED } \\
\text { ENERGY } \\
\text { EE/AREA }\end{array}$} & \multicolumn{3}{|c|}{ DIFFERENCE } \\
\hline & & & $\begin{array}{c}\text { \% of OE } \\
\text { DIFFERENCE }\end{array}$ & $\begin{array}{c}\% \text { of EE } \\
\text { DIFFERENCE } \\
\end{array}$ & $\begin{array}{c}\text { EE factor } \\
\text { EE/OE }\end{array}$ \\
\hline & kBtu/ftt/year & kBtu/ftt/year & & & \\
\hline ASHRAE Benchmark (U=0.51) & 80.436 & 8.155 & & & \\
\hline Most optimum & 66.655 & 10.366 & -17.134 & 27.122 & 0.156 \\
\hline \multicolumn{6}{|l|}{ ORIENTATION } \\
\hline$(-) 90$ & 77.860 & 8.260 & -3.202 & 1.287 & 0.106 \\
\hline$(-) 45$ & 78.162 & 8.260 & -2.827 & 1.287 & 0.106 \\
\hline$(+) 180$ & 79.838 & 8.260 & -0.744 & 1.287 & 0.103 \\
\hline$(+) 90$ & 77.709 & 8.260 & -3.391 & 1.287 & 0.106 \\
\hline$(+) 45$ & 79.233 & 8.260 & -1.495 & 1.287 & 0.104 \\
\hline \multicolumn{6}{|l|}{ GLAZING } \\
\hline Low-e & 75.648 & 8.271 & -5.953 & 1.431 & 0.109 \\
\hline Insulated reflective low-e & 73.663 & 8.274 & -8.421 & 1.469 & 0.112 \\
\hline 2-pane low-e & 73.034 & 8.340 & -9.203 & 2.273 & 0.114 \\
\hline 3-pane low-e & 72.460 & 8.392 & -9.916 & 2.910 & 0.116 \\
\hline \multicolumn{6}{|l|}{ SHADING } \\
\hline 1/6 window height & 79.577 & 8.265 & -1.069 & 1.349 & 0.104 \\
\hline $1 / 4$ window height & 79.666 & 8.268 & -0.958 & 1.389 & 0.104 \\
\hline $1 / 3$ window height & 79.173 & 8.271 & -1.570 & 1.429 & 0.104 \\
\hline $1 / 2$ window height & 78.625 & 8.278 & -2.251 & 1.510 & 0.105 \\
\hline 2/3 window height & 78.475 & 8.284 & -2.439 & 1.590 & 0.106 \\
\hline \multicolumn{6}{|l|}{ WINDOW TO WALL RATIO } \\
\hline $15 \%$ & 71.649 & 8.601 & -10.924 & 5.478 & 0.120 \\
\hline $30 \%$ & 79.184 & 8.205 & -1.557 & 0.615 & 0.104 \\
\hline $40 \%$ & 81.268 & 8.025 & 1.035 & -1.586 & 0.099 \\
\hline $50 \%$ & 83.390 & 7.913 & 3.672 & -2.959 & 0.095 \\
\hline \multicolumn{6}{|l|}{ ROOF CONSTRUCTION } \\
\hline Q1 & 76.477 & 8.460 & -4.922 & 3.747 & 0.111 \\
\hline Q2 & 76.391 & 8.632 & -5.029 & 5.860 & 0.113 \\
\hline Q3 & 75.454 & 8.676 & -6.194 & 6.392 & 0.115 \\
\hline $\mathrm{Q} 4$ & 75.360 & 10.089 & -6.311 & 23.721 & 0.134 \\
\hline
\end{tabular}




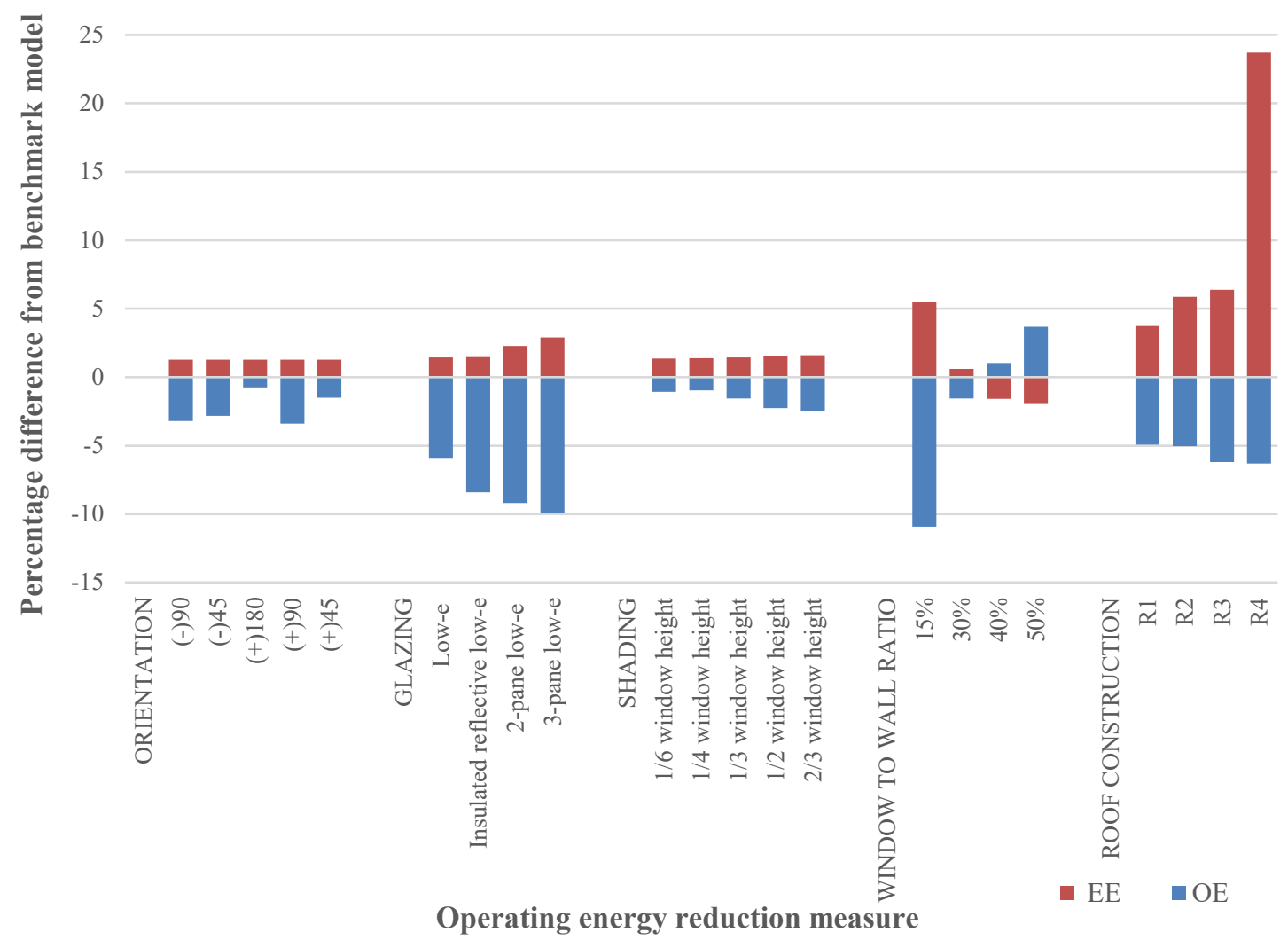

Figure 2 EE variation caused by applying OE reduction measures on Assembly 1 b

Upon changing the orientation of the building (Figures 2-5), no differences were observed in the EE demand across construction assemblies. This is mainly because additional material was not added to the baseline model. 
Table 5 Summary of OE and EE variation, along with EE factor for wall assembly $2 \mathrm{~b}$, in a heating dominated region

\begin{tabular}{|c|c|c|c|c|c|}
\hline \multirow{4}{*}{$\begin{array}{l}\text { MEASURES FOR OE } \\
\text { REDUCTION }\end{array}$} & \multicolumn{5}{|c|}{ ASSEMBLY 2b (U=0.039) } \\
\hline & \multirow{2}{*}{$\begin{array}{c}\text { OPERATING } \\
\text { ENERGY } \\
\text { EUI }\end{array}$} & \multirow{2}{*}{$\begin{array}{c}\text { EMBODIED } \\
\text { ENERGY } \\
\text { EE / AREA }\end{array}$} & \multicolumn{3}{|c|}{ DIFFERENCE } \\
\hline & & & $\begin{array}{c}\text { \% of OE } \\
\text { DIFFERENCE }\end{array}$ & $\begin{array}{c}\% \text { of EE } \\
\text { DIFFERENCE }\end{array}$ & $\begin{array}{c}\text { EE } \\
\text { factor } \\
\text { EE/OE }\end{array}$ \\
\hline & kBtu / ft² /year & kBtu / ft ${ }^{2} /$ year & & & \\
\hline ASHRAE Benchmark (U=0.51) & 80.436 & 8.155 & & & \\
\hline Most optimum & 66.413 & 10.374 & -17.434 & 27.216 & 0.156 \\
\hline \multicolumn{6}{|l|}{ ORIENTATION } \\
\hline$(-) 90$ & 77.589 & 8.264 & -3.539 & 1.344 & 0.107 \\
\hline$(-) 45$ & 77.831 & 8.264 & -3.238 & 1.344 & 0.106 \\
\hline$(+) 180$ & 79.612 & 8.264 & -1.025 & 1.344 & 0.104 \\
\hline$(+) 90$ & 77.425 & 8.264 & -3.743 & 1.344 & 0.107 \\
\hline$(+) 45$ & 78.892 & 8.264 & -1.919 & 1.344 & 0.105 \\
\hline \multicolumn{6}{|l|}{ GLAZING } \\
\hline Low-e & 75.409 & 8.277 & -6.249 & 1.506 & 0.110 \\
\hline Insulated reflective low-e & 73.278 & 8.280 & -8.900 & 1.542 & 0.113 \\
\hline 2-pane low-e & 72.678 & 8.345 & -9.645 & 2.330 & 0.115 \\
\hline 3-pane low-e & 72.177 & 8.398 & -10.268 & 2.985 & 0.116 \\
\hline \multicolumn{6}{|l|}{ SHADING } \\
\hline 1/6 window height & 79.221 & 8.269 & -1.510 & 1.406 & 0.104 \\
\hline $1 / 4$ window height & 79.372 & 8.271 & -1.323 & 1.431 & 0.104 \\
\hline $1 / 3$ window height & 78.868 & 8.276 & -1.949 & 1.485 & 0.105 \\
\hline $1 / 2$ window height & 78.271 & 8.282 & -2.692 & 1.565 & 0.106 \\
\hline $2 / 3$ window height & 78.056 & 8.287 & -2.960 & 1.627 & 0.106 \\
\hline \multicolumn{6}{|l|}{ WINDOW TO WALL RATIO } \\
\hline $15 \%$ & 71.223 & 8.609 & -11.453 & 5.571 & 0.121 \\
\hline $30 \%$ & 78.897 & 8.204 & -1.914 & 0.607 & 0.104 \\
\hline $40 \%$ & 81.072 & 8.053 & 0.791 & -1.243 & 0.099 \\
\hline $50 \%$ & 83.211 & 7.916 & 3.449 & -2.922 & 0.095 \\
\hline \multicolumn{6}{|l|}{ ROOF CONSTRUCTION } \\
\hline Q1 & 76.250 & 8.465 & -5.205 & 3.802 & 0.111 \\
\hline Q2 & 76.149 & 8.637 & -5.329 & 5.915 & 0.113 \\
\hline Q3 & 75.213 & 8.680 & -6.494 & 6.447 & 0.115 \\
\hline Q4 & 75.112 & 10.095 & -6.619 & 23.794 & 0.134 \\
\hline
\end{tabular}




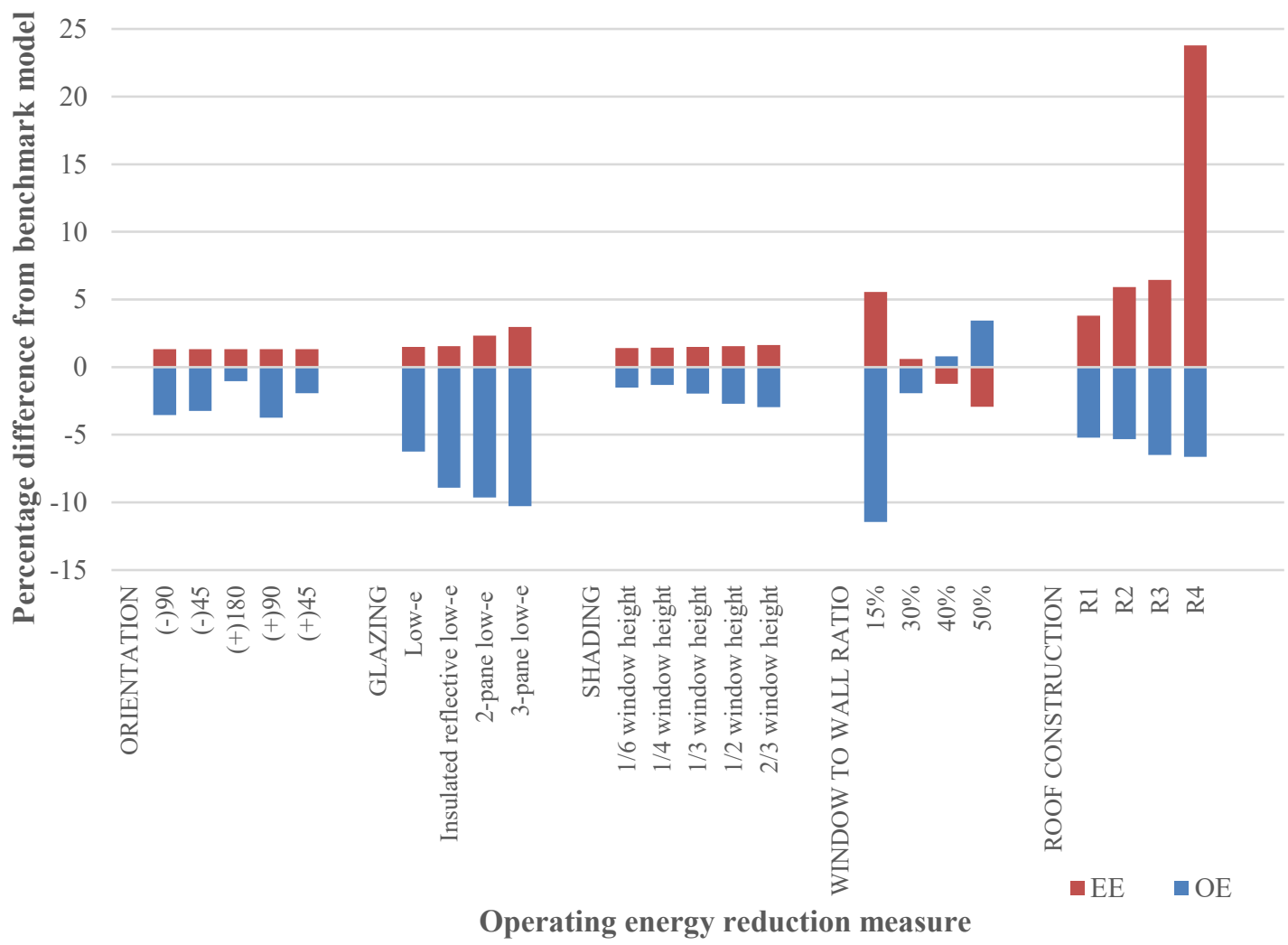

Figure 3 EE variation caused by applying OE reduction measures on Assembly $2 b$

The second $\mathrm{OE}$ reduction measure of changing the glazing system for wall assembly 1-4 showed the following results. For wall assembly $1 \mathrm{~b}$ (Table 4 ) and $2 \mathrm{~b}$ (Table 5), we observed 6-10\% decrease in OE for 1.5-3\% increase in EE. For wall assembly $3 b$ (Table 6), we found that 6.6-10.5\% decrease in OE results in increasing the EE from 2.5$4 \%$ (Figure 4). In the case, of wall assembly $4 \mathrm{~b}$ (Table 7 ), we noticed that $7.5-11.5 \%$ decrease in OE subsequently increases the EE from 3-4.5\% (Figure 5). While we compare the results across wall assembly 1-4, we find that the percentage of OE savings per unit of EE spent as we approach assembly $4 \mathrm{~b}$ (higher insulation level), is much lesser when compared with assembly $1 \mathrm{~b}$ (less insulation). 
Table 6 Summary of OE and EE variation, along with EE factor for wall assembly $3 \mathrm{~b}$, in a heating dominated region

\begin{tabular}{|c|c|c|c|c|c|}
\hline \multirow{4}{*}{$\begin{array}{l}\text { MEASURES FOR OE } \\
\text { REDUCTION }\end{array}$} & \multicolumn{5}{|c|}{ ASSEMBLY 3b $(\mathrm{U}=\mathbf{0 . 0 3 6})$} \\
\hline & \multirow{2}{*}{$\begin{array}{c}\text { OPERATING } \\
\text { ENERGY } \\
\text { EUI }\end{array}$} & \multirow{2}{*}{$\begin{array}{c}\text { EMBODIED } \\
\text { ENERGY } \\
\text { EE / AREA }\end{array}$} & \multicolumn{3}{|c|}{ DIFFERENCE } \\
\hline & & & $\begin{array}{c}\% \text { of OE } \\
\text { DIFFERENCE }\end{array}$ & $\begin{array}{c}\% \text { of EE } \\
\text { DIFFERENCE }\end{array}$ & $\begin{array}{c}\text { EE } \\
\text { factor } \\
\text { EE/OE }\end{array}$ \\
\hline & kBtu / ft $^{2} /$ year & kBtu / ft $^{2} /$ year & & & \\
\hline ASHRAE Benchmark $(\mathrm{U}=\mathbf{0 . 5 1})$ & 80.436 & 8.155 & & & \\
\hline Most optimum & 66.298 & 10.470 & -17.577 & 28.393 & 0.158 \\
\hline \multicolumn{6}{|l|}{ ORIENTATION } \\
\hline$(-) 90$ & 77.192 & 8.339 & -4.034 & 2.263 & 0.108 \\
\hline$(-) 45$ & 77.562 & 8.339 & -3.573 & 2.263 & 0.108 \\
\hline$(+) 180$ & 79.243 & 8.339 & -1.484 & 2.263 & 0.105 \\
\hline$(+) 90$ & 77.044 & 8.339 & -4.217 & 2.263 & 0.108 \\
\hline$(+) 45$ & 78.621 & 8.339 & -2.257 & 2.263 & 0.106 \\
\hline \multicolumn{6}{|l|}{ GLAZING } \\
\hline Low-e & 75.050 & 8.352 & -6.696 & 2.425 & 0.111 \\
\hline Insulated reflective low-e & 72.990 & 8.409 & -9.257 & 3.124 & 0.115 \\
\hline 2-pane low-e & 72.347 & 8.420 & -10.057 & 3.249 & 0.116 \\
\hline 3-pane low-e & 71.968 & 8.474 & -10.528 & 3.922 & 0.118 \\
\hline \multicolumn{6}{|l|}{ SHADING } \\
\hline 1/6 window height & 78.929 & 8.481 & -1.874 & 4.002 & 0.107 \\
\hline 1/4 window height & 79.018 & 8.483 & -1.763 & 4.024 & 0.107 \\
\hline $1 / 3$ window height & 78.482 & 8.486 & -2.430 & 4.064 & 0.108 \\
\hline $1 / 2$ window height & 77.878 & 8.493 & -3.180 & 4.146 & 0.109 \\
\hline $2 / 3$ window height & 77.650 & 8.499 & -3.464 & 4.226 & 0.109 \\
\hline \multicolumn{6}{|l|}{ WINDOW TO WALL RATIO } \\
\hline $15 \%$ & 70.862 & 8.668 & -11.902 & 6.293 & 0.122 \\
\hline $30 \%$ & 78.460 & 8.263 & -2.457 & 1.328 & 0.105 \\
\hline $40 \%$ & 80.720 & 8.109 & 0.353 & -0.555 & 0.100 \\
\hline $50 \%$ & 82.948 & 7.980 & 3.122 & -2.136 & 0.096 \\
\hline \multicolumn{6}{|l|}{ ROOF CONSTRUCTION } \\
\hline Q1 & 75.892 & 8.700 & -5.650 & 6.685 & 0.115 \\
\hline Q2 & 75.809 & 8.872 & -5.753 & 8.797 & 0.117 \\
\hline Q3 & 74.859 & 8.915 & -6.934 & 9.330 & 0.119 \\
\hline Q4 & 74.759 & 10.328 & -7.058 & 26.658 & 0.138 \\
\hline
\end{tabular}




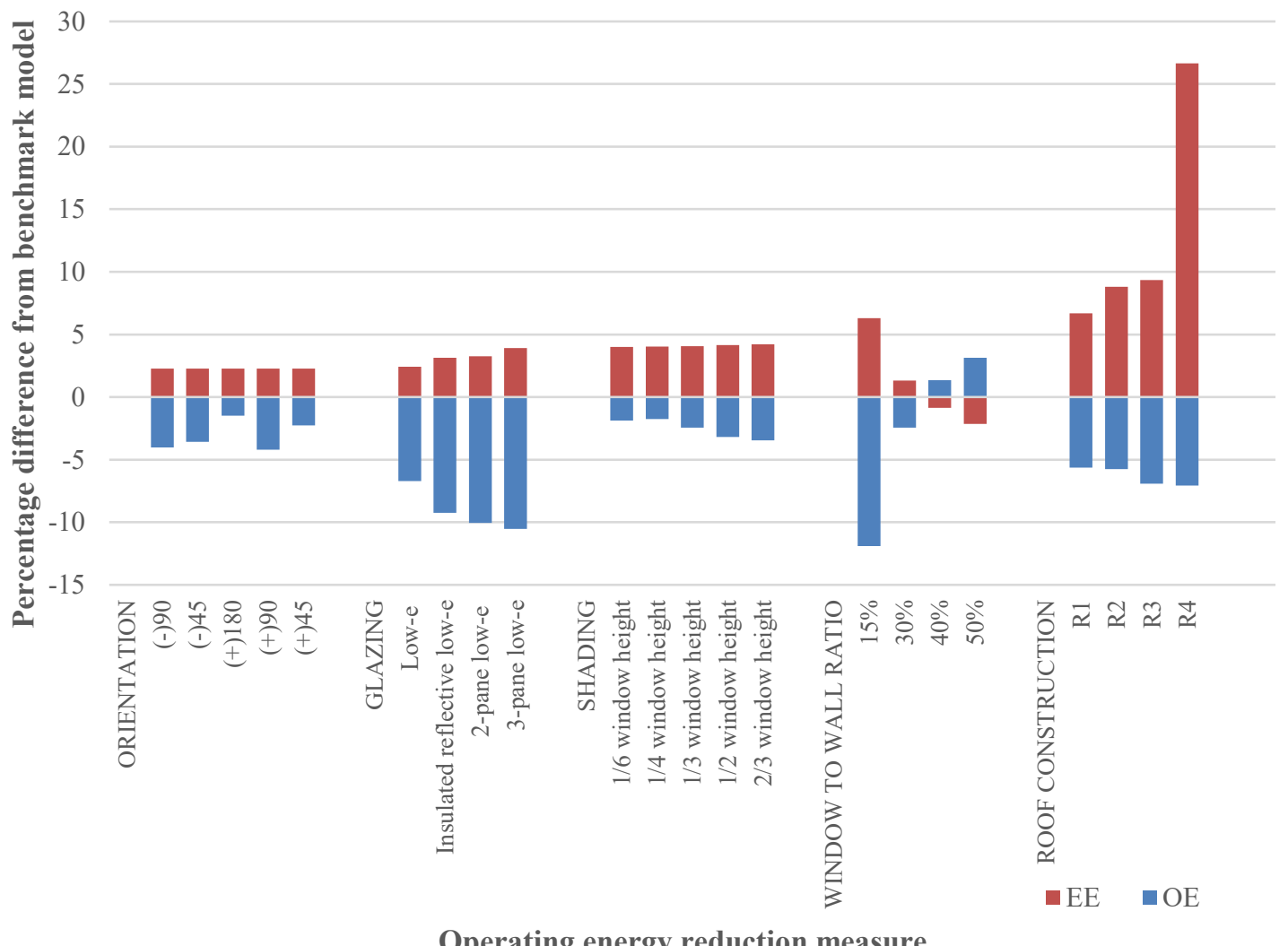

Figure 4 EE variation caused by applying OE reduction measures on Assembly $3 b$

The third OE reduction measure was to change the shading depth from 1/6 times the window height to $2 / 3$ times the window height, for wall assembly $1 b-4 b$. Amongst all the study cases for different wall assembly - that fall under the shade depth category, it was found that the shade depth of 1/6 times the window height had the highest EUI. For wall assembly $1 \mathrm{~b}$, saving approximately $1-2.5 \%$ of $\mathrm{OE}$, results in spending $1.3-1.5 \%$ of EE (Table 4). For wall assembly $2 b$, we save around $1.5-3 \%$ of $\mathrm{OE}$ and spend $1.4-1.6 \%$ of EE (Table 5). For wall assembly $3 b$, OE reduction is calculated as $1.8-3.5 \%$, while EE increase ranges between 3.5-4 \% (Table 6). For wall assembly $4 b, 3-5 \%$ of OE, results in 
spending 4.5 to $4.7 \%$ of EE (Table 7). In terms of EUI, the most optimal window depth was found to be $2 / 3$ times the window height, in all the study cases for wall assembly $1 \mathrm{~b}$ $4 b$.

Table 7 Summary of OE and EE variation, along with EE factor for wall assembly $4 \mathrm{~b}$, in a heating dominated region

\begin{tabular}{|c|c|c|c|c|c|}
\hline \multirow{4}{*}{$\begin{array}{l}\text { MEASURES FOR OE } \\
\text { REDUCTION }\end{array}$} & \multicolumn{5}{|c|}{ ASSEMBLY $4 b(\mathrm{U}=0.033)$} \\
\hline & \multirow{2}{*}{$\begin{array}{c}\text { OPERATING } \\
\text { ENERGY } \\
\text { EUI }\end{array}$} & \multirow{2}{*}{$\begin{array}{c}\text { EMBODIED } \\
\text { ENERGY } \\
\text { EE / AREA }\end{array}$} & \multicolumn{3}{|c|}{ DIFFERENCE } \\
\hline & & & $\begin{array}{c}\% \text { of OE } \\
\text { DIFFERENCE }\end{array}$ & $\begin{array}{c}\% \text { of EE } \\
\text { DIFFERENCE }\end{array}$ & $\begin{array}{c}\text { EE } \\
\text { factor } \\
\text { EE/OE }\end{array}$ \\
\hline & kBtu / ft²/year & kBtu / ft²/year & & & \\
\hline ASHRAE Benchmark $(\mathrm{U}=0.51)$ & 80.436 & 8.155 & & & \\
\hline Most optimum & 66.170 & 10.520 & -17.736 & 29.012 & 0.159 \\
\hline \multicolumn{6}{|l|}{ ORIENTATION } \\
\hline$(-) 90$ & 76.548 & 8.378 & -4.834 & 2.740 & 0.109 \\
\hline$(-) 45$ & 77.017 & 8.378 & -4.251 & 2.740 & 0.109 \\
\hline$(+) 180$ & 78.668 & 8.378 & -2.199 & 2.740 & 0.106 \\
\hline$(+) 90$ & 76.399 & 8.378 & -5.019 & 2.740 & 0.110 \\
\hline$(+) 45$ & 78.033 & 8.378 & -2.988 & 2.740 & 0.107 \\
\hline \multicolumn{6}{|l|}{ GLAZING } \\
\hline Low-e & 74.467 & 8.391 & -7.421 & 2.902 & 0.113 \\
\hline Insulated reflective low-e & 72.260 & 8.450 & -10.164 & 3.622 & 0.117 \\
\hline 2-pane low-e & 71.646 & 8.460 & -10.929 & 3.744 & 0.118 \\
\hline 3-pane low-e & 71.225 & 8.513 & -11.452 & 4.400 & 0.120 \\
\hline \multicolumn{6}{|l|}{ SHADING } \\
\hline 1/6 window height & 78.464 & 8.520 & -2.452 & 4.479 & 0.109 \\
\hline $1 / 4$ window height & 78.367 & 8.523 & -2.572 & 4.521 & 0.109 \\
\hline $1 / 3$ window height & 77.818 & 8.527 & -3.255 & 4.561 & 0.110 \\
\hline $1 / 2$ window height & 77.158 & 8.532 & -4.076 & 4.623 & 0.111 \\
\hline $2 / 3$ window height & 76.835 & 8.538 & -4.476 & 4.703 & 0.111 \\
\hline \multicolumn{6}{|l|}{ WINDOW TO WALL RATIO } \\
\hline $15 \%$ & 71.330 & 8.604 & -11.322 & 5.510 & 0.121 \\
\hline $30 \%$ & 78.966 & 8.208 & -1.828 & 0.655 & 0.104 \\
\hline $40 \%$ & 81.126 & 8.056 & 0.858 & -1.210 & 0.099 \\
\hline $50 \%$ & 83.260 & 7.976 & 3.511 & -2.186 & 0.096 \\
\hline \multicolumn{6}{|l|}{ ROOF CONSTRUCTION } \\
\hline Q1 & 75.291 & 8.714 & -6.397 & 6.859 & 0.116 \\
\hline Q2 & 75.196 & 8.886 & -6.515 & 8.972 & 0.118 \\
\hline Q3 & 74.254 & 8.930 & -7.686 & 9.504 & 0.120 \\
\hline Q4 & 74.151 & 10.344 & -7.814 & 26.852 & 0.140 \\
\hline
\end{tabular}




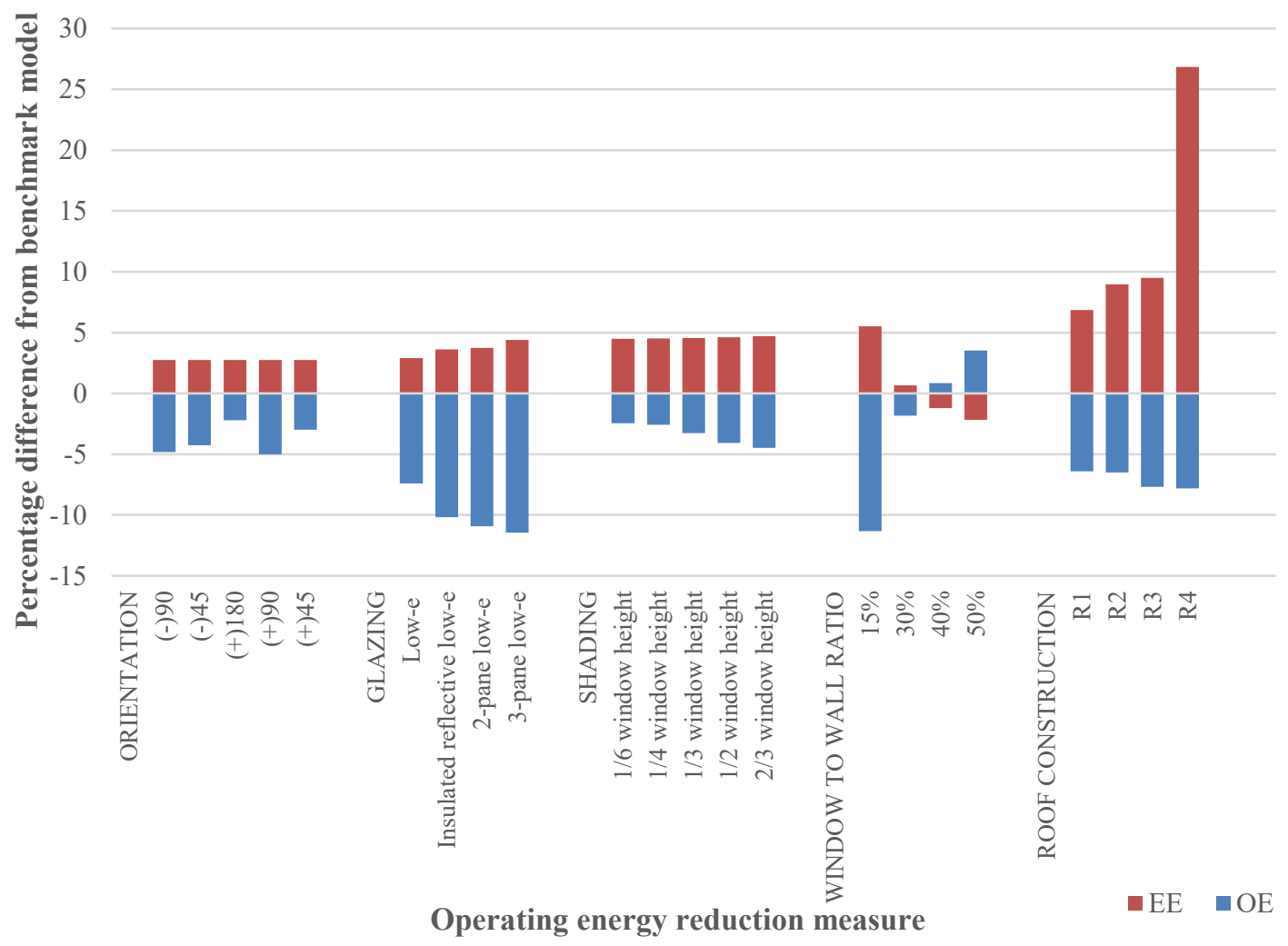

Figure 5 EE variation caused by applying OE reduction measures on Assembly 4b

The fourth OE reduction measure of changing the WWR from $15-50 \%$ was performed on wall assembly $1 b-4 b$. For wall assembly $1 b-4 b$ changing the WWR to $15 \%$ causes approximately $11-12 \%$ decrease in OE, and nearly $5.5-6 \%$ increase in EE (as seen in Figures 2-4), while the WWR of 50\% showed an increase in OE by $3.5 \%$ and decrease in EE demand by $2.13-3 \%$.

The final OE reduction measure, calculates the implications of changing the roof assembly Q1(R-30) to Q4 (R-45) on OE and EE components. For wall assembly 1b and 
$2 \mathrm{~b}$, it was found that decreasing OE by $5-7 \%$, resulted in increasing EE by $4-24 \%$ (as seen in Figure 2). For wall assembly 3b, OE savings was calculated as 6-7\%, while EE spent was between $7-27 \%$. For wall assembly $4 \mathrm{~b}, 6-8 \%$ decrease in OE resulted in increasing the EE by $7-27 \%$. The overall results indicate that as we approach more insulated wall assemblies; there are lesser improvements to the EUI, while the embodied energy consumption increases.

To further investigate the impacts of $\mathrm{OE}$ reduction measures on $\mathrm{EE}$, a combination of measures was applied on the baseline model to determine overall $\mathrm{OE}$ and $\mathrm{EE}$ implications. OE reduction measures that had the most impact under each category was manually selected from the matrix (Tables 4-7). These measures include, building orientation at (+90), 3-pane window glazing system, WWR of 15\%, 36 in shade depth and Q4 (R-45) roof assembly. The subsequent impacts on the EE were observed. The simulated results show that the most optimized model created for wall assembly $1 \mathrm{~b}$, had an $\mathrm{OE}$ reduction of $17.1 \%$, while the EE increased by $27.12 \%$ (Figure 6). Therefore, the EE factor for the most optimized version of wall assembly 1, was found to be 0.155 . This implies that for every $1 \mathrm{kBtu}$ increase in $\mathrm{OE}, 0.155 \mathrm{kBtu}$ of EE is expended. The most optimized version of wall assembly 2 showed an OE decrease of $17.43 \%$, and an associated $27.21 \%$ increase in EE. The EE factor in this case was found to be 0.156 . For wall assembly 3 , decreasing the OE by $17.57 \%$, resulted in increasing EE by $28.39 \%$. The EE factor was found to be 0.157 . For wall assembly 4, decreasing the OE by $17.73 \%$, caused a $29.01 \%$ increase in EE. The EE factor is 0.158 . 


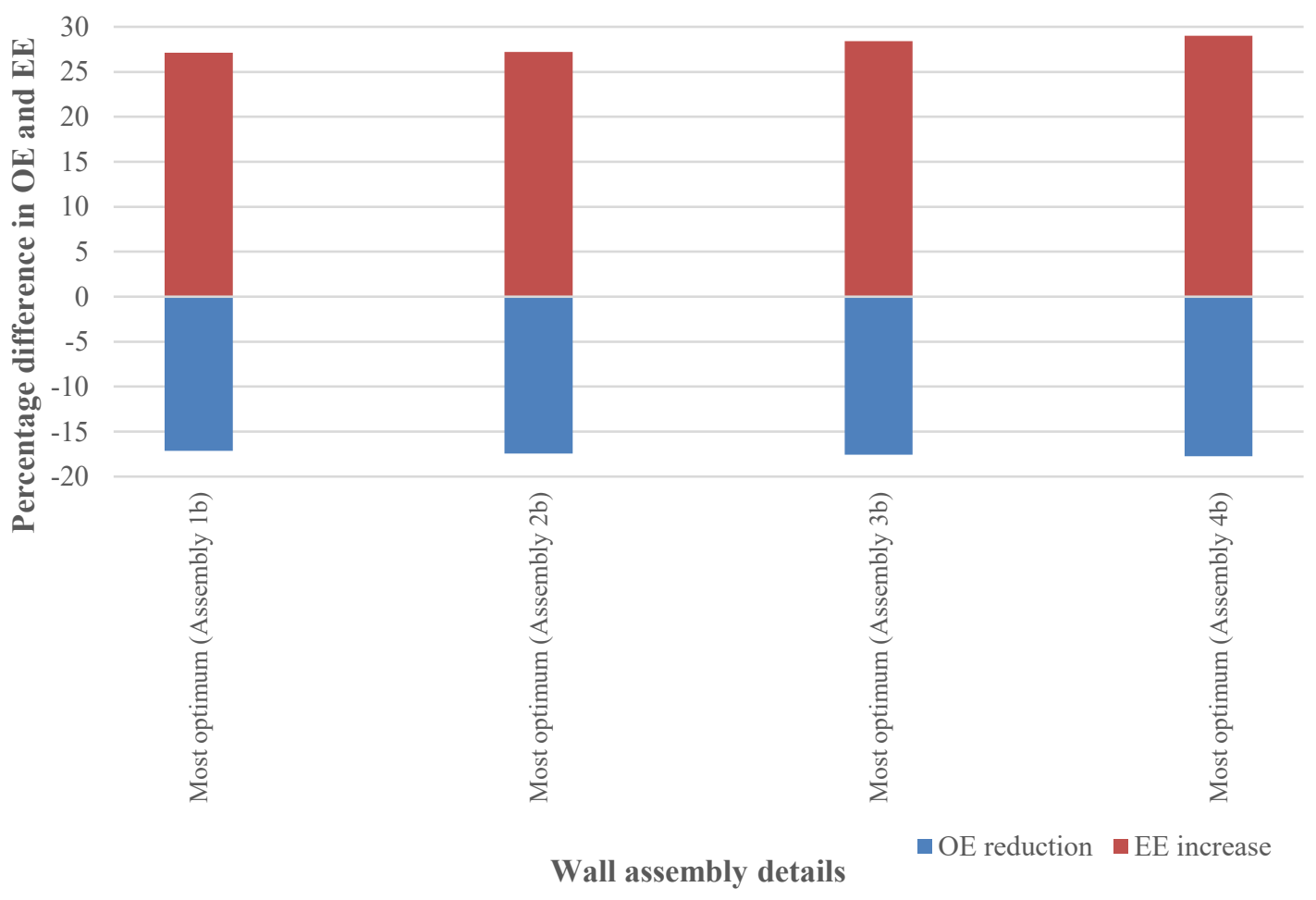

Figure 6 OE vs EE evaluation for the most optimized model across different wall assemblies (climate zone $5 \mathrm{~A}$ )

The OE of a building can be further categorized into space heating loads, space cooling loads, and lighting loads. Figure 7 shows the energy trade-offs occur within OE components as well. For wall assembly $1 \mathrm{~b}$, changing the glazing system from low-e glass to 3-pane low-e glass or changing the shading depth from 9in to 36in results in decreasing the space cooling, while increasing space heating and lighting loads. Upon changing the WWR from $15 \%$ to $50 \%$ we observe the lighting load dramatically decreasing. This is attributed to the higher amounts of daylight entering the building. However, increasing the surface area of glass also results in increasing the space conditioning loads. Changing the 
level of insulation in the roof increases the cooling energy demand while decreasing the heating energy demand. This may be due to the increased level of insulation that results in trapping heat within the building for long time durations.

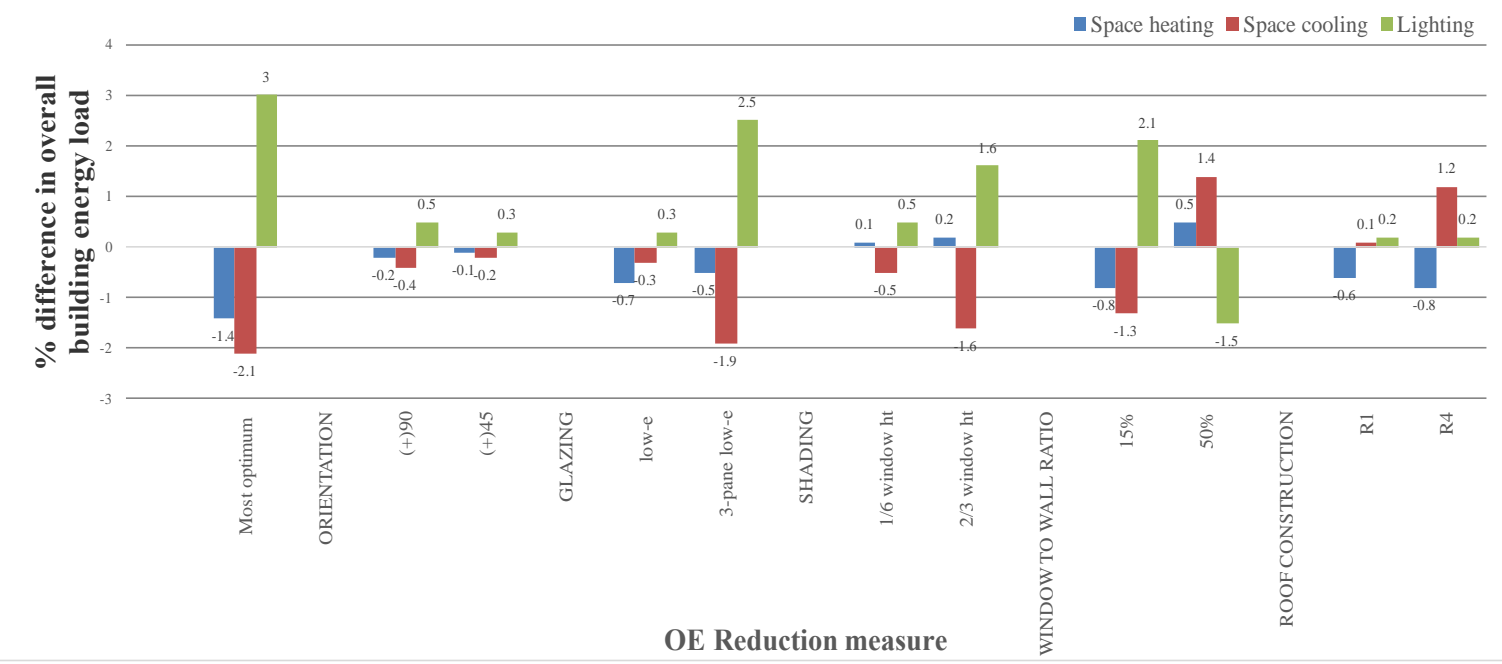

Figure $7 \mathrm{OE}$ trade-offs for wall assembly $1 \mathrm{~b}$ (climate zone 5A)

\subsection{Cooling dominated region (climate zone $2 \mathrm{~A}$ )}

For climate zone 2A, we observed that the ASHRAE 90.1-2016, benchmark model has an EUI of $46.2 \mathrm{kBtu} / \mathrm{ft}^{2} / \mathrm{year}$, while the embodied energy consumption is 7.8 $\mathrm{kBtu} / \mathrm{ft}^{2} / \mathrm{year}$ (Tables 8-11). Overall, across the four assemblies the OE shows a reducing trend, while the EE shows an increasing trend (Figures 8-11). 
Table 8 Summary of OE and EE variation, along with EE factor for wall assembly $1 \mathrm{a}$, in a heating dominated region

\begin{tabular}{|c|c|c|c|c|c|}
\hline \multirow{3}{*}{$\begin{array}{l}\text { MEASURES FOR OE } \\
\text { REDUCTION }\end{array}$} & \multicolumn{5}{|c|}{ ASSEMBLY 1a $(U=0.066)$} \\
\hline & \multirow{2}{*}{$\begin{array}{c}\begin{array}{c}\text { OPERATING } \\
\text { ENERGY }\end{array} \\
\text { EUI } \\
\text { kBtu / } \mathrm{ft}^{2} \text { / year }\end{array}$} & \multirow{2}{*}{$\begin{array}{c}\text { EMBODIED } \\
\text { ENERGY } \\
\text { EE/Area } \\
\text { kBtu / } \\
\text { ft }^{2} / \text { year } \\
\end{array}$} & \multicolumn{3}{|c|}{ DIFFERENCE } \\
\hline & & & $\begin{array}{c}\% \text { of OE } \\
\text { DIFFERENCE }\end{array}$ & $\begin{array}{c}\% \text { of EE } \\
\text { DIFFERENCE }\end{array}$ & $\begin{array}{c}\text { EE } \\
\text { factor } \\
\text { EE/OE }\end{array}$ \\
\hline ASHRAE Benchmark (U=0.075) & 46.2 & 7.832 & & & \\
\hline Most optimum & 39.5 & 9.910 & -14.502 & 26.537 & 0.251 \\
\hline \multicolumn{6}{|l|}{ ORIENTATION } \\
\hline$(-) 90$ & 45.5 & 7.942 & -1.515 & 1.410 & 0.175 \\
\hline$(-) 45$ & 45.8 & 7.942 & -0.866 & 1.410 & 0.173 \\
\hline$(+) 180$ & 45.6 & 7.942 & -1.299 & 1.410 & 0.174 \\
\hline$(+) 90$ & 45.4 & 7.942 & -1.732 & 1.410 & 0.175 \\
\hline$(+) 45$ & 45.7 & 7.942 & -1.082 & 1.410 & 0.174 \\
\hline \multicolumn{6}{|l|}{ GLAZING } \\
\hline low-e & 45.1 & 7.956 & -2.381 & 1.591 & 0.176 \\
\hline Insulated reflective low-e & 43.4 & 7.964 & -6.061 & 1.693 & 0.184 \\
\hline 2-pane low-e & 43.2 & 8.023 & -6.494 & 2.442 & 0.186 \\
\hline 3-pane low-e & 41.7 & 8.078 & -9.740 & 3.150 & 0.194 \\
\hline \multicolumn{6}{|l|}{ SHADING } \\
\hline $1 / 6$ window height & 45 & 7.980 & -2.597 & 1.896 & 0.177 \\
\hline $1 / 3$ window height & 44.4 & 8.008 & -3.896 & 2.252 & 0.180 \\
\hline $1 / 4$ window height & 44.7 & 8.003 & -3.247 & 2.185 & 0.179 \\
\hline $1 / 2$ window height & 43.9 & 8.039 & -4.978 & 2.641 & 0.183 \\
\hline $2 / 3$ window height & 43.5 & 8.053 & -5.844 & 2.822 & 0.185 \\
\hline \multicolumn{6}{|l|}{ WINDOW TO WALL RATIO } \\
\hline $15 \%$ & 42.7 & 7.974 & -7.576 & 1.817 & 0.187 \\
\hline $30 \%$ & 45.1 & 7.958 & -2.381 & 1.608 & 0.176 \\
\hline $40 \%$ & 46.5 & 7.908 & 0.649 & 0.979 & 0.170 \\
\hline $50 \%$ & 48 & 7.891 & 3.896 & 0.757 & 0.164 \\
\hline \multicolumn{6}{|l|}{ ROOF CONSTRUCTION } \\
\hline Q1 & 44.6 & 7.862 & -3.463 & 0.385 & 0.176 \\
\hline Q2 & 44.2 & 7.965 & -4.329 & 1.698 & 0.180 \\
\hline Q3 & 44.4 & 8.090 & -3.896 & 3.304 & 0.182 \\
\hline Q4 & 43.9 & 9.455 & -4.978 & 20.732 & 0.215 \\
\hline
\end{tabular}




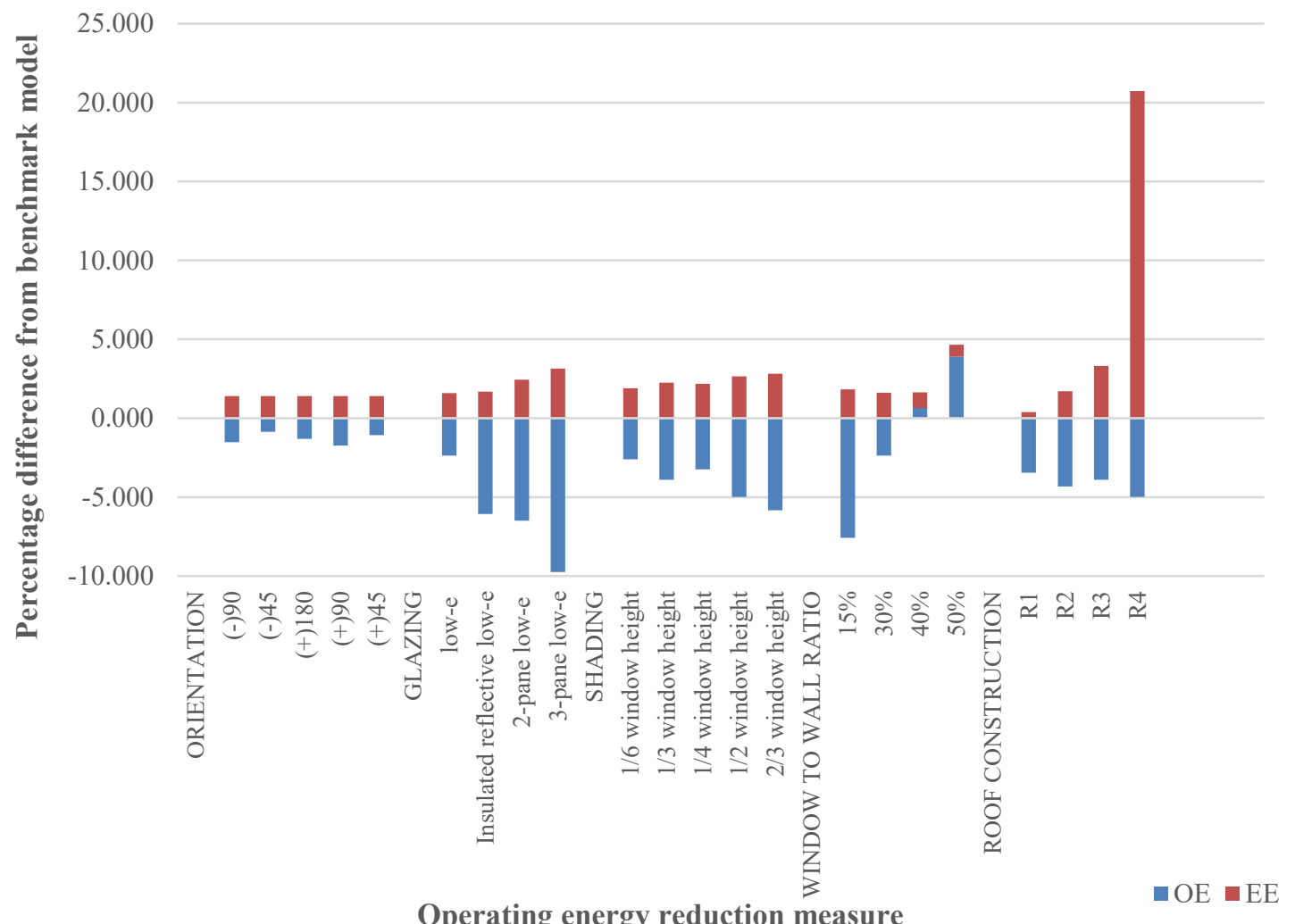

Figure 8 EE variation caused by applying OE reduction measures on Assembly 1a

For the first $\mathrm{OE}$ reduction strategy of changing the orientation, we found a similarity in the results between the two climate zones. Across the four assemblies, the model had the least energy consumption, when the project North was facing east. In both the cases (climate zone $2 \mathrm{~A}$ and $5 \mathrm{~A}$ ), the $\mathrm{EE}$ does not show any variation since no additional material was added to the model. 
Table 9 Summary of OE and EE variation, along with EE factor for wall assembly 2a, in a heating dominated region

\begin{tabular}{|c|c|c|c|c|c|}
\hline \multirow{3}{*}{$\begin{array}{l}\text { MEASURES FOR OE } \\
\text { REDUCTION }\end{array}$} & \multicolumn{5}{|c|}{ ASSEMBLY 2a $(\mathrm{U}=0.052)$} \\
\hline & \multirow{2}{*}{$\begin{array}{c}\text { OPERATING } \\
\text { ENERGY } \\
\text { EUI } \\
\text { kBtu / } \text { ft }^{2} / \text { year }\end{array}$} & \multirow{2}{*}{$\begin{array}{l}\text { EMBODIED } \\
\text { ENERGY } \\
\text { EE/Area } \\
\mathrm{kBtu} / \mathrm{ft}^{2} / \text { year }\end{array}$} & \multicolumn{3}{|c|}{ DIFFERENCE } \\
\hline & & & $\begin{array}{c}\% \text { of OE } \\
\text { DIFFERENCE }\end{array}$ & $\begin{array}{c}\% \text { of EE } \\
\text { DIFFERENCE }\end{array}$ & $\begin{array}{c}\text { EE factor } \\
\text { EE/OE }\end{array}$ \\
\hline ASHRAE Benchmark $(\mathrm{U}=\mathbf{0 . 0 7 5})$ & 46.200 & 7.832 & & & \\
\hline Most optimum & 39.100 & 10.136 & -15.368 & 29.428 & 0.259 \\
\hline \multicolumn{6}{|l|}{ ORIENTATION } \\
\hline$(-) 90$ & 45.100 & 8.086 & -2.381 & 3.244 & 0.179 \\
\hline$(-) 45$ & 45.400 & 8.086 & -1.732 & 3.244 & 0.178 \\
\hline$(+) 180$ & 45.200 & 8.086 & -2.165 & 3.244 & 0.179 \\
\hline$(+) 90$ & 45.400 & 8.086 & -1.732 & 3.244 & 0.178 \\
\hline$(+) 45$ & 45.300 & 8.086 & -1.948 & 3.244 & 0.178 \\
\hline \multicolumn{6}{|l|}{ GLAZING } \\
\hline low-e & 44.900 & 8.100 & -2.814 & 3.429 & 0.180 \\
\hline Insulated reflective low-e & 43.100 & 8.104 & -6.710 & 3.481 & 0.188 \\
\hline 2-pane low-e & 43.000 & 8.166 & -6.926 & 4.268 & 0.190 \\
\hline 3-pane low-e & 41.300 & 8.376 & -10.606 & 6.952 & 0.203 \\
\hline \multicolumn{6}{|l|}{ SHADING } \\
\hline $1 / 6$ window height & 44.700 & 8.094 & -3.247 & 3.350 & 0.181 \\
\hline $1 / 3$ window height & 44.000 & 8.100 & -4.762 & 3.420 & 0.184 \\
\hline $1 / 4$ window height & 44.500 & 8.097 & -3.680 & 3.389 & 0.182 \\
\hline $1 / 2$ window height & 43.700 & 8.108 & -5.411 & 3.525 & 0.186 \\
\hline $2 / 3$ window height & 43.200 & 8.115 & -6.494 & 3.622 & 0.188 \\
\hline \multicolumn{6}{|l|}{ WINDOW TO WALL RATIO } \\
\hline $15 \%$ & 42.500 & 8.431 & -8.009 & 7.653 & 0.198 \\
\hline $30 \%$ & 44.900 & 8.086 & -2.814 & 3.241 & 0.180 \\
\hline $40 \%$ & 46.300 & 7.934 & 0.216 & 1.305 & 0.171 \\
\hline $50 \%$ & 47.900 & 7.798 & 3.680 & -0.428 & 0.163 \\
\hline \multicolumn{6}{|l|}{ ROOF CONSTRUCTION } \\
\hline Q1 & 44.400 & 8.281 & -3.896 & 5.740 & 0.187 \\
\hline Q2 & 43.900 & 8.367 & -4.978 & 6.831 & 0.191 \\
\hline Q3 & 44.300 & 8.410 & -4.113 & 7.379 & 0.190 \\
\hline Q4 & 43.700 & 9.623 & -5.411 & 22.869 & 0.220 \\
\hline
\end{tabular}




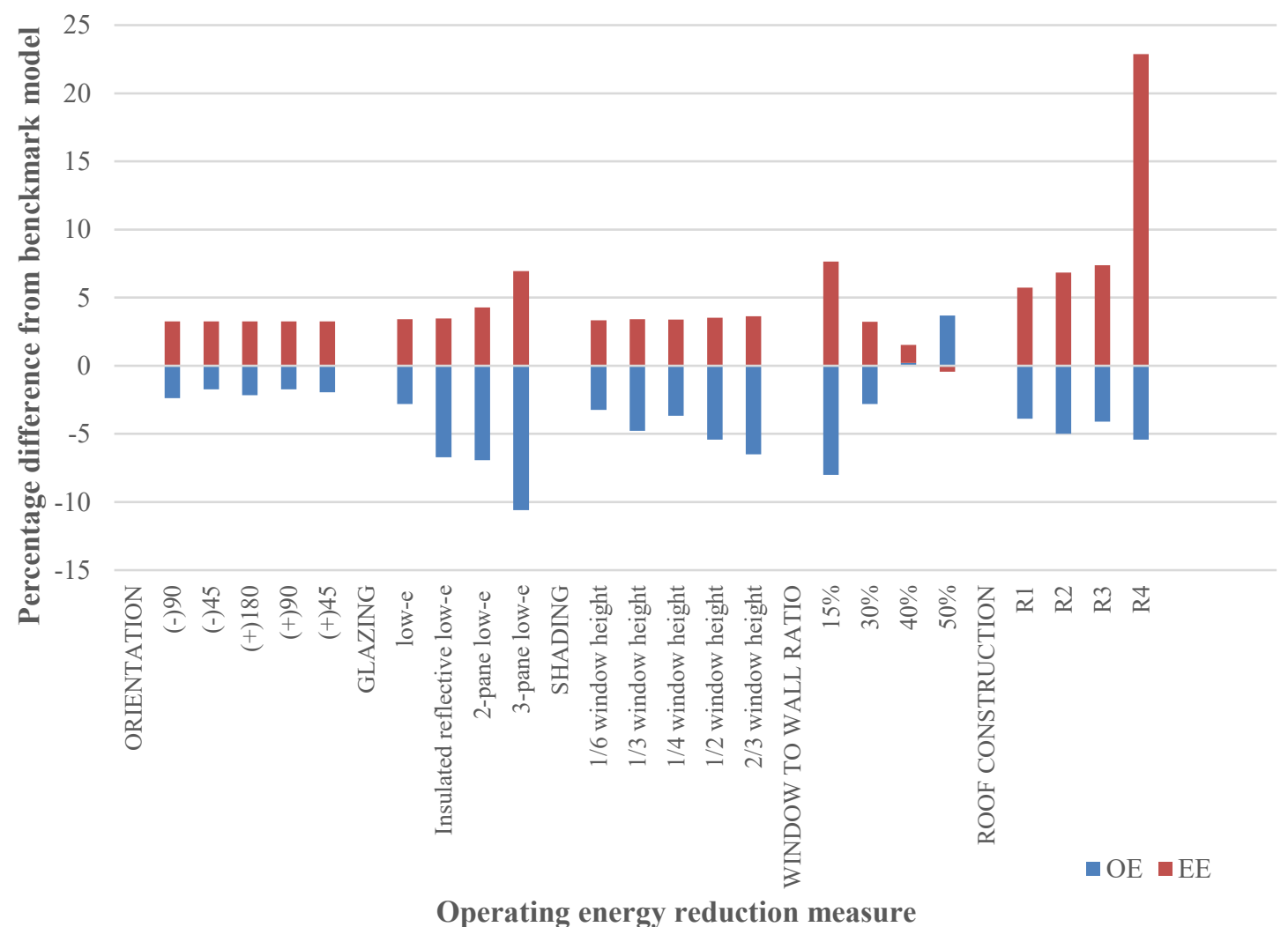

Figure 9 EE variation caused by applying OE reduction measures on Assembly 2a

For the second OE reduction measure of changing the glazing system used in the building. For wall assembly 1a, we found that OE decreased by $2.3-9.7 \%$, while the EE increased by $1.6-3 \%$ (Table 8 ). For wall assembly 2a, saving 3-11\% of OE, subsequently increased EE by 3.5-7.0\% (Table 9). For wall assembly 3a, we calculated a 4-12\% decrease in OE, while the EE increased by 4-6\% (Table 10). For wall assembly 4a, a 4$12 \%$ decrease in $\mathrm{OE}$, resulted in EE increase by 6-8\% (Table 11). 
Table 10 Summary of $\mathrm{OE}$ and $\mathrm{EE}$ variation, along with $\mathrm{EE}$ factor for wall assembly 3a, in a heating dominated region

\begin{tabular}{|c|c|c|c|c|c|}
\hline \multirow{3}{*}{$\begin{array}{l}\text { MEASURES FOR OE } \\
\text { REDUCTION }\end{array}$} & \multicolumn{5}{|c|}{ ASSEMBLY 3a $(\mathrm{U}=0.047)$} \\
\hline & \multirow{2}{*}{$\begin{array}{c}\begin{array}{c}\text { OPERATING } \\
\text { ENERGY }\end{array} \\
\text { EUI } \\
\text { kBtu / } \text { ft }^{2} \text { / year }\end{array}$} & \multirow{2}{*}{$\begin{array}{l}\text { EMBODIED } \\
\text { ENERGY } \\
\text { EE/Area } \\
\text { kBtu / ft } 2 / \text { year }\end{array}$} & \multicolumn{3}{|c|}{ DIFFERENCE } \\
\hline & & & $\begin{array}{c}\% \text { of OE } \\
\text { DIFFERENCE }\end{array}$ & $\begin{array}{c}\% \text { of EE } \\
\text { DIFFERENCE }\end{array}$ & $\begin{array}{c}\text { EE factor } \\
\text { EE/OE }\end{array}$ \\
\hline ASHRAE Benchmark $(\mathrm{U}=0.075)$ & 46.200 & 7.832 & & & \\
\hline Most optimum & 38.400 & 10.186 & -16.883 & 30.056 & 0.265 \\
\hline \multicolumn{6}{|l|}{ ORIENTATION } \\
\hline$(-) 90$ & 44.800 & 8.164 & -3.030 & 4.246 & 0.182 \\
\hline$(-) 45$ & 44.900 & 8.164 & -2.814 & 4.246 & 0.182 \\
\hline$(+) 180$ & 44.800 & 8.164 & -3.030 & 4.246 & 0.182 \\
\hline$(+) 90$ & 44.700 & 8.164 & -3.247 & 4.246 & 0.183 \\
\hline$(+) 45$ & 44.900 & 8.164 & -2.814 & 4.246 & 0.182 \\
\hline \multicolumn{6}{|l|}{ GLAZING } \\
\hline low-e & 44.400 & 8.184 & -3.896 & 4.500 & 0.184 \\
\hline Insulated reflective low-e & 42.900 & 8.206 & -7.143 & 4.785 & 0.191 \\
\hline 2-pane low-e & 42.600 & 8.217 & -7.792 & 4.925 & 0.193 \\
\hline 3-pane low-e & 40.700 & 8.292 & -11.905 & 5.878 & 0.204 \\
\hline \multicolumn{6}{|l|}{ SHADING } \\
\hline 1/6 window height & 44.500 & 8.201 & -3.680 & 4.715 & 0.184 \\
\hline $1 / 3$ window height & 43.800 & 8.258 & -5.195 & 5.444 & 0.189 \\
\hline $1 / 4$ window height & 44.100 & 8.218 & -4.545 & 4.927 & 0.186 \\
\hline $1 / 2$ window height & 43.200 & 8.349 & -6.494 & 6.605 & 0.193 \\
\hline $2 / 3$ window height & 42.800 & 8.386 & -7.359 & 7.077 & 0.196 \\
\hline \multicolumn{6}{|l|}{ WINDOW TO WALL RATIO } \\
\hline $15 \%$ & 41.900 & 8.216 & -9.307 & 4.908 & 0.196 \\
\hline $30 \%$ & 44.300 & 8.183 & -4.113 & 4.484 & 0.185 \\
\hline $40 \%$ & 45.900 & 7.973 & -0.649 & 1.803 & 0.174 \\
\hline $50 \%$ & 47.500 & 7.867 & 2.814 & 0.452 & 0.166 \\
\hline \multicolumn{6}{|l|}{ ROOF CONSTRUCTION } \\
\hline Q1 & 44.100 & 8.321 & -4.545 & 6.250 & 0.189 \\
\hline Q2 & 43.600 & 8.500 & -4.762 & 8.527 & 0.195 \\
\hline Q3 & 44.000 & 8.552 & -5.628 & 9.194 & 0.194 \\
\hline Q4 & 43.200 & 9.703 & -6.494 & 23.888 & 0.225 \\
\hline
\end{tabular}




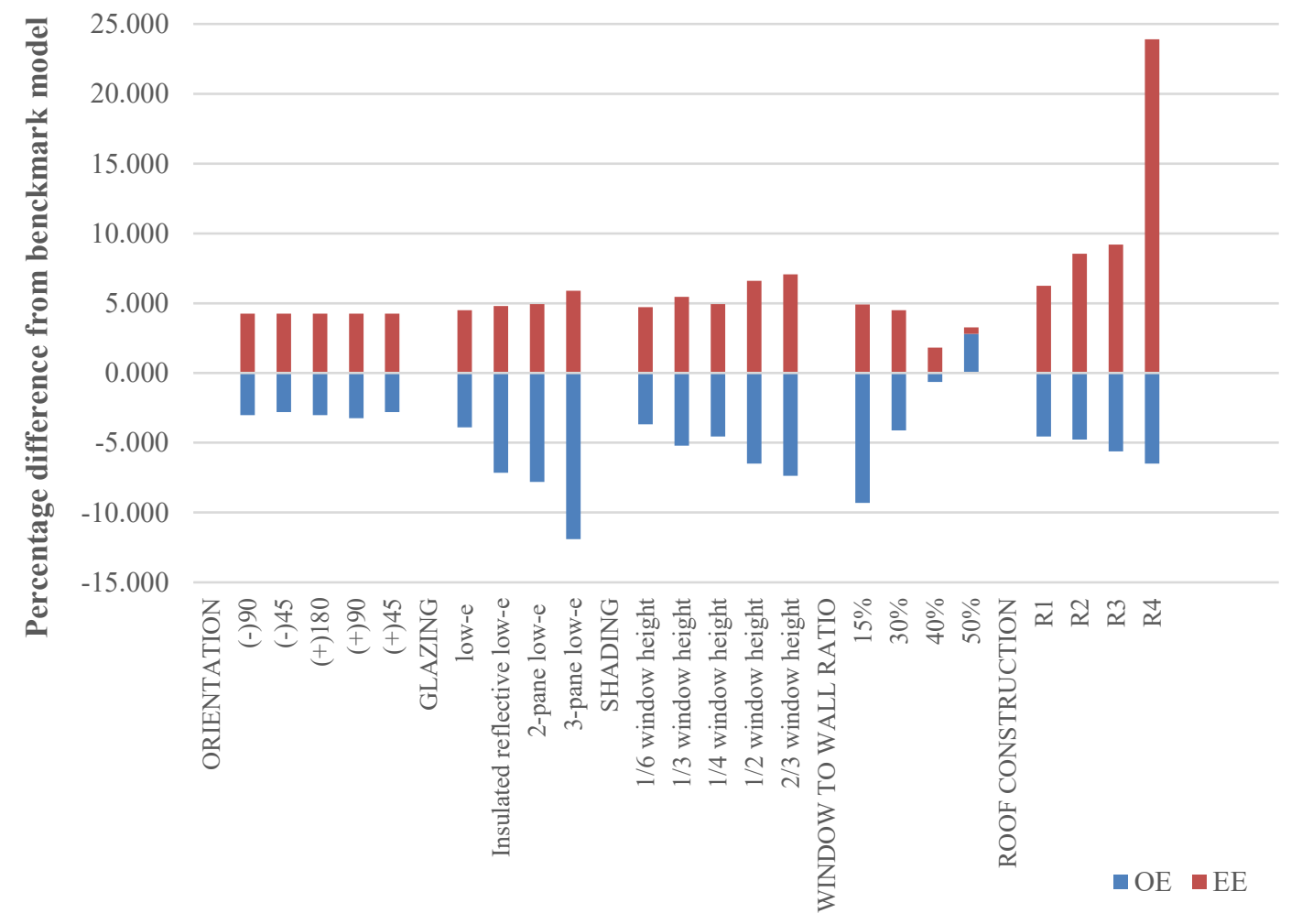

Operating energy reduction measure

Figure 10 EE variation caused by applying OE reduction measures on Assembly 3a

Upon applying the third OE reduction measure of changing the shading depth, from 9 in to 36 in the following results were observed. For wall assembly 1a, 3-6\% decrease in OE resulted in increasing EE by 2-3\%. For wall assembly 2a, saving OE by 3$6 \%$ subsequently resulted in spending $3-4 \%$ of EE. For wall assembly $3 a$, we observe that OE reduces by $4-7 \%$ while EE increases by $5-7 \%$. For wall assembly 4 a, reducing OE by 5-8\% increases EE by 7-8\%. 
Table 11 Summary of $\mathrm{OE}$ and EE variation, along with EE factor for wall assembly $4 a$, in a heating dominated region

\begin{tabular}{|c|c|c|c|c|c|}
\hline \multirow{3}{*}{$\begin{array}{l}\text { MEASURES FOR OE } \\
\text { REDUCTION }\end{array}$} & \multicolumn{5}{|c|}{ ASSEMBLY 4a $(U=0.037)$} \\
\hline & \multirow{2}{*}{$\begin{array}{c}\begin{array}{c}\text { OPERATING } \\
\text { ENERGY }\end{array} \\
\text { EUI } \\
\text { kBtu / } \text { ft }^{2} \text { / year }\end{array}$} & \multirow{2}{*}{ 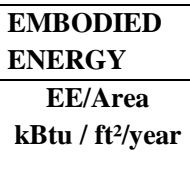 } & \multicolumn{3}{|c|}{ DIFFERENCE } \\
\hline & & & $\begin{array}{c}\% \text { of OE } \\
\text { DIFFERENC } \\
\text { E }\end{array}$ & $\begin{array}{c}\% \text { of EE } \\
\text { DIFFERENCE }\end{array}$ & $\begin{array}{c}\text { EE } \\
\text { factor } \\
\text { EE/OE }\end{array}$ \\
\hline $\begin{array}{l}\text { ASHRAE Benchmark } \\
(\mathbf{U}=0.075)\end{array}$ & 46.200 & 7.832 & & & \\
\hline Most optimum & 38.100 & 10.210 & -17.532 & 30.367 & 0.268 \\
\hline \multicolumn{6}{|l|}{ ORIENTATION } \\
\hline$(-) 90$ & 44.600 & 8.290 & -3.463 & 5.850 & 0.186 \\
\hline$(-) 45$ & 44.800 & 8.290 & -3.030 & 5.850 & 0.185 \\
\hline$(+) 180$ & 44.700 & 8.290 & -3.247 & 5.850 & 0.185 \\
\hline$(+) 90$ & 44.600 & 8.290 & -3.463 & 5.850 & 0.186 \\
\hline$(+) 45$ & 44.700 & 8.290 & -3.247 & 5.850 & 0.185 \\
\hline \multicolumn{6}{|l|}{ GLAZING } \\
\hline low-e & 44.200 & 8.339 & -4.329 & 6.475 & 0.189 \\
\hline Insulated reflective low-e & 42.600 & 8.348 & -7.792 & 6.588 & 0.196 \\
\hline 2-pane low-e & 42.400 & 8.373 & -8.225 & 6.911 & 0.197 \\
\hline 3-pane low-e & 40.500 & 8.484 & -12.338 & 8.335 & 0.209 \\
\hline \multicolumn{6}{|l|}{ SHADING } \\
\hline 1/6 window height & 44.100 & 8.342 & -4.545 & 6.518 & 0.189 \\
\hline $1 / 3$ window height & 43.500 & 8.351 & -5.844 & 6.625 & 0.192 \\
\hline $1 / 4$ window height & 43.800 & 8.346 & -5.195 & 6.567 & 0.191 \\
\hline $1 / 2$ window height & 43.000 & 8.478 & -6.926 & 8.251 & 0.197 \\
\hline $2 / 3$ window height & 42.600 & 8.495 & -7.792 & 8.466 & 0.199 \\
\hline \multicolumn{6}{|l|}{ WINDOW TO WALL RATIO } \\
\hline $15 \%$ & 41.400 & 8.612 & -10.390 & 9.963 & 0.208 \\
\hline $30 \%$ & 44.100 & 8.285 & -4.545 & 5.793 & 0.188 \\
\hline $40 \%$ & 45.700 & 8.167 & -1.082 & 4.276 & 0.179 \\
\hline $50 \%$ & 47.300 & 8.054 & 2.381 & 2.837 & 0.170 \\
\hline \multicolumn{6}{|l|}{ ROOF CONSTRUCTION } \\
\hline Q1 & 43.900 & 8.509 & -4.978 & 8.645 & 0.194 \\
\hline Q2 & 43.800 & 8.713 & -5.195 & 11.256 & 0.205 \\
\hline Q3 & 43.500 & 8.917 & -5.844 & 13.862 & 0.199 \\
\hline Q4 & 43.300 & 9.928 & -6.277 & 26.770 & 0.229 \\
\hline
\end{tabular}




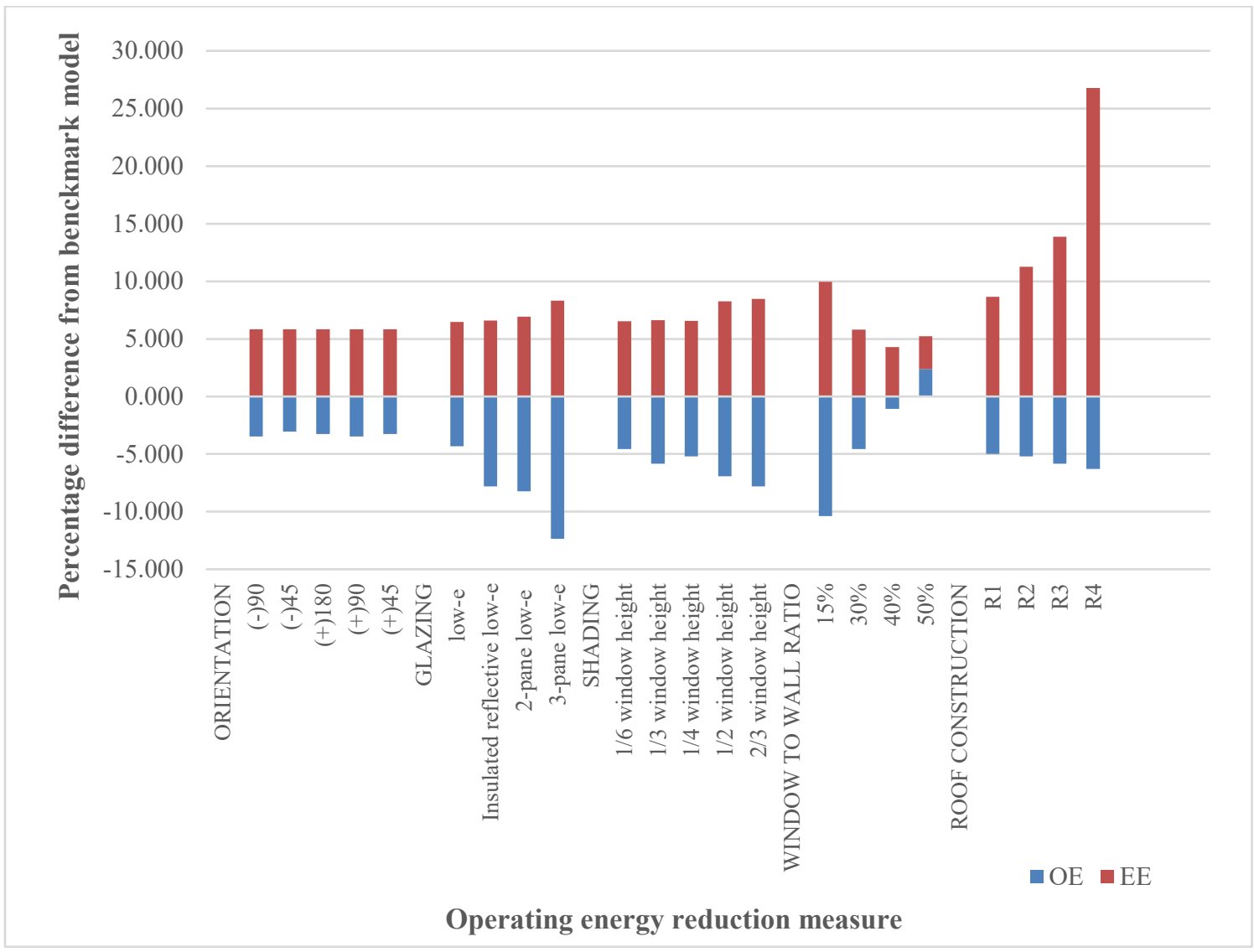

Figure 11 EE variation caused by applying OE reduction measures on Assembly 4a

Upon applying the final OE reduction measure of changing the insulation level (R30 to R-45), the following implication were observed on the $\mathrm{OE}$ and EE components. For wall assembly 1a, decreasing 3-4\% OE resulted in increasing 5-20\% of EE. For wall assembly 2a, decreasing 3-5\% OE, caused an increase of 6-23\% in EE. For wall assembly 3a, decreasing 4.5-6\% OE, accounted for increasing 6-25\% of EE. For wall assembly 4a, decreasing 5-6 \% OE, increase EE by 8-26\%. From the above results, we can conclude that changing the insulation levels in the roof has higher impact on the EE of a building when compared with OE. 
To further emphasis upon the conflicting impacts of the OE reduction measures on EE. We created an optimized model using the process mentioned earlier in the study. For the hot-humid climate of Houston, we observed that for wall assembly 1a, reducing the OE by $14.5 \%$, resulted in increasing the EE by $26.5 \%$. For wall assembly 2 a, reducing the OE by $15.3 \%$, resulted in increasing the EE by $29.4 \%$. For wall assembly 3 a, reducing the OE by $16.8 \%$, resulted in increasing the EE by $30.05 \%$. For wall assembly $4 a$, reducing the OE by $17.5 \%$, resulted in increasing the EE by $31.6 \%$. The EE factor for the most optimized model varies from 0.25 to 0.26 , across the different assemblies (Figure 12). These results show that improvements that are focused upon reducing operating energy are not sufficient to reduce overall building energy. 


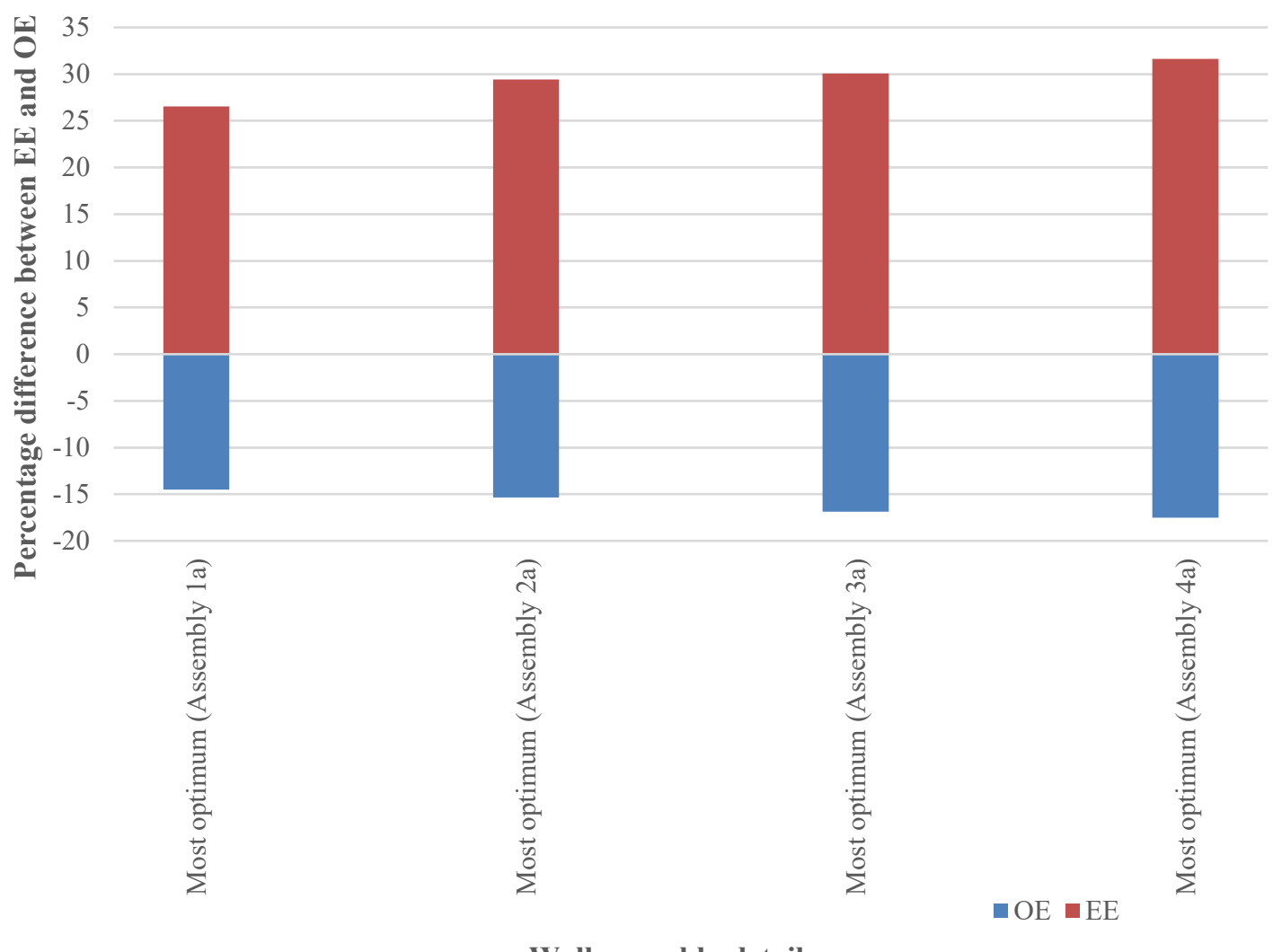

Figure $12 \mathrm{OE}$ vs EE evaluation for the most optimized model across different wall assemblies (climate zone 2A)

For the hot-humid climate of Houston, we observe that for assembly 1a changing the glazing system or the level of shading does not have any impact on the space heating loads. In both the cases, the space cooling demand reduces while the lighting load increases. Changing the WWR from $15 \%$ to $50 \%$, increases space cooling need while decreasing the lighting loads. Changing the level of insulation in the roofs reduced the cooling needs, while the lighting and heating requirements remained constant (Figure 13). 


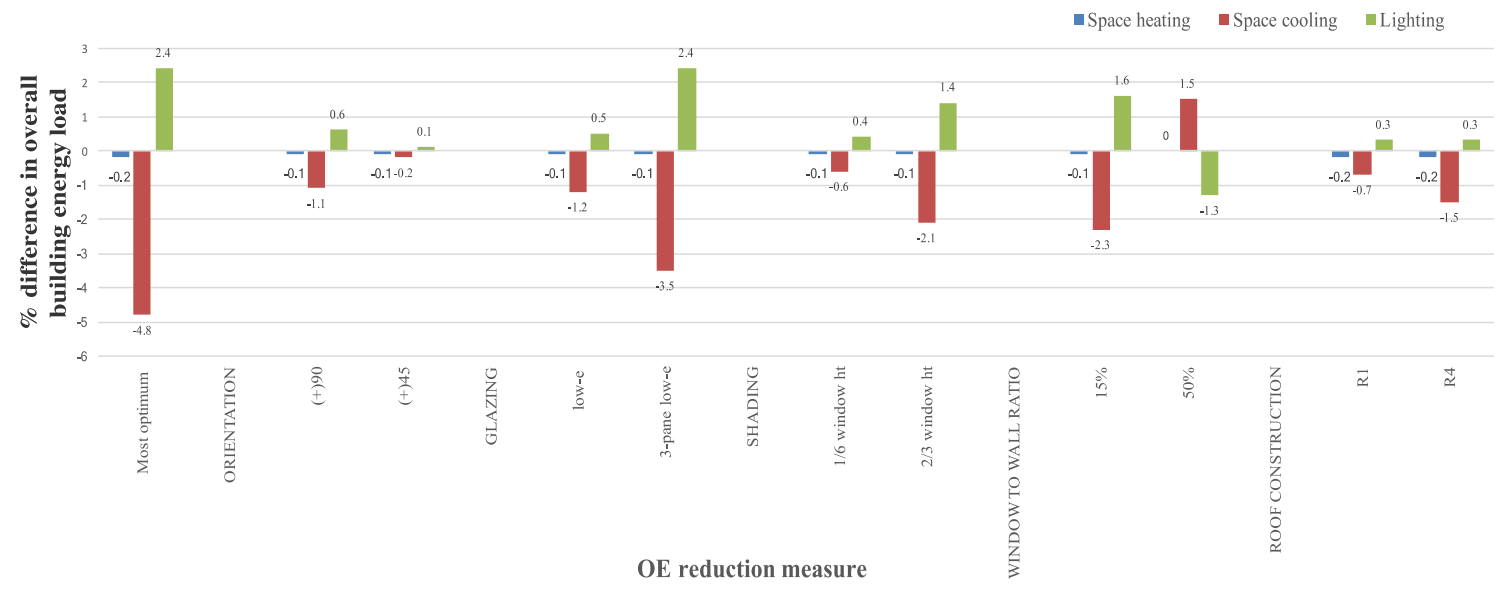

Figure 13 OE trade-offs for wall assembly 1a (climate zone 2A) 


\section{DISCUSSION}

According to the literature review, we were able to identify five major clusters into which these OE reduction measures can be categorized. They were level of insulation (walls and roofs), building orientation, type of glazing system, depth of external shading, and window to wall ratio. For the typical ASHRAE 90.1, 2016 benchmark model, the application of these OE reduction measures shows different influences upon the overall building LCE.

Upon changing the orientation as an $\mathrm{OE}$ reduction measure it was found that the EUI decreases when the project north faces east $(+90)$ in all our study cases. This implies that the longer building was aligned across the north-south direction. In addition, the EUI of the study cases across different construction assemblies showed very minor differences upon rotating the entire building by 180 degrees. This is because the baseline model is symmetrical over the building's central axis.

From the above calculations, changing the depth of the external shades, shows satisfactory benefits in terms of OE and EE demands. These benefits are evident from the gradient diagrams (Figure 2-5), since the negative values of $\mathrm{OE}$ and positive values of $\mathrm{EE}$ almost balance each other out. However, it is important to select the optimal overhang depth to obtain higher energy savings. Our study shows that the depth of the overhang directly correlates with the height of the window. This statement is further corroborated by the study conducted by Bellia et al. (2013) and Huang et al. (2012). Moreover, the 
functionality of the shades is used to its maximum potential only when they block the direct solar irradiance from hitting the glazing surface. In this regard of varying shade depths, the overall result obtained from our study is contradictory to the results obtained from the study performed by Huang et al. (2012). In their study, they found that LCE benefits from the use of external shading for a building located in Hong Kong, causes a negative impact, when it comes to EE consumption. This difference in results can be largely attributed to the difference in material used for the external shades and the climatic conditions of the studies.

The window to wall ratio has a significant impact on the overall energy consumption in a building. From our calculations, it was observed that reducing the WWR, increased the EE demand in the building. This is because the insulation material (XPS, EPS etc.) used in the wall assembly has much higher EE than that of glass. Thereby implying that the findings of our study are similar to the results found by Utama and Gheewala (2009). In addition, Yohanis and Norton (2002) found that a building that has a WWR of $15 \%$ has the least OE demand, which validates the findings of our study. Increasing the insulation thickness has positive implications on reducing the $\mathrm{OE}$ demand. However, our study observed that beyond a certain thickness, the insulation does not help with OE reduction. This is because greater levels of insulation increase the time lag, thereby trapping the heat that entered the building for long time durations. As a result, the cooling loads and EE loads of a building, eventually starts increasing. The findings of our study are supported by several other studies such as Rodrigues and Freire (2017), Utama and Gheewala (2009), and Radhi (2009). 
The results obtained from our study show that the overall EE factor for the optimized model varies between $0.156-0.159$ in climate zone $5 \mathrm{~A}$ and $0.259-0.268$ in climate zone $2 \mathrm{~A}$ across construction assemblies. Thereby, indicating that the EE factor is much higher in climate zone $2 \mathrm{~A}$ in comparison with climate zone $5 \mathrm{~A}$. Furthermore, we compared the results of our study with literature. Collinge et al. (2013) conducted a LCA of an institutional building (Benedum Hall, University of Pittsburgh) in the United states over a 75-year lifespan. The annual OE consumption in their study was found to be $345.175 \mathrm{kBtu} / \mathrm{ft}^{2} /$ year, this is much higher than the EUI we obtained in our study. This can be attributed to the additional loads (occupancy, plug, hot water) that was considered in the system boundary of their study. The EE demand is $5.9 \mathrm{kBtu} / \mathrm{ft}^{2} / \mathrm{year}$ resulting in an EE factor of 0.017. Scheuer et al. (2003) conducted a LCA of a six-storey building located in the University of Michigan campus for a 75-year life span of the building. The annual OE consumption was $361.025 \mathrm{kBtu} / \mathrm{ft}^{2} /$ year and EE consumption was $7.3 \mathrm{kBtu} / \mathrm{ft}^{2} /$ year. Thereby, resulting in an EE factor of 0.020. The study by Junnila et al. (2006) conducted a LCA on a five-storey office building in the Midwest region of the United States. The annual OE consumption was $119.754 \mathrm{kBtu} / \mathrm{ft}^{2} /$ year, while the EE was $13.9 \mathrm{kBtu} / \mathrm{ft}^{2} /$ year. In this case, we calculated the EE factor as 0.116 . The variation in results across the studies might be due to the difference in the type of material used, construction method, climatic zone and system boundary considered in each case. This makes it difficult to compare the results obtained from our study with existing literature.

In addition, the study faced several challenges to run energy simulation using a BIM enhanced approach. The previously suggested workflow of extracting material 
information from Autodesk Revit into GBS had issues of interoperability, since the Uvalues of all the materials were not exported accurately. While certain $U$-values of the materials used in a particular construction assembly were as per the required specification; the specification of certain materials were not replicated as required. In this case, default U-values of the materials were used from the GBS library. To resolve this issue, we used pre-populated lists of construction assembly data, that was readily available in GBS to generate results for our study cases. The whole process became extremely timeconsuming, since the results of GBS had to be verified using another energy simulation tool called e-Quest. As seen in Figure 14 and 15, the variation in the results generated from e-quest and GBS for wall assembly $1 \mathrm{a}$ and $4 \mathrm{a}$ were similar. The models were not calibrated to show similar EUI, since we were only concerned with their absolute differences. 


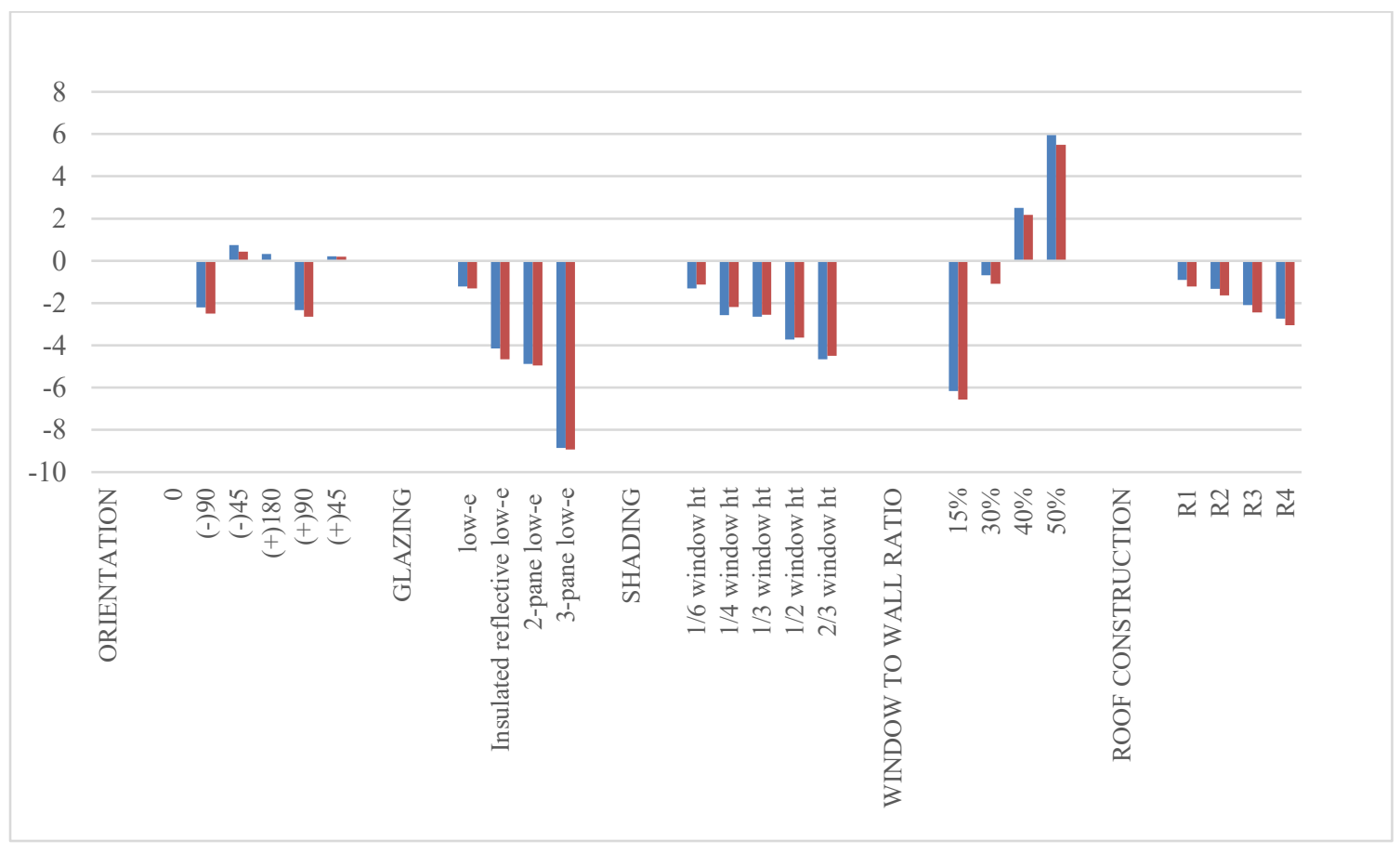

Figure 14 e-Quest vs GBS, variation in EUI, for wall assembly 1a

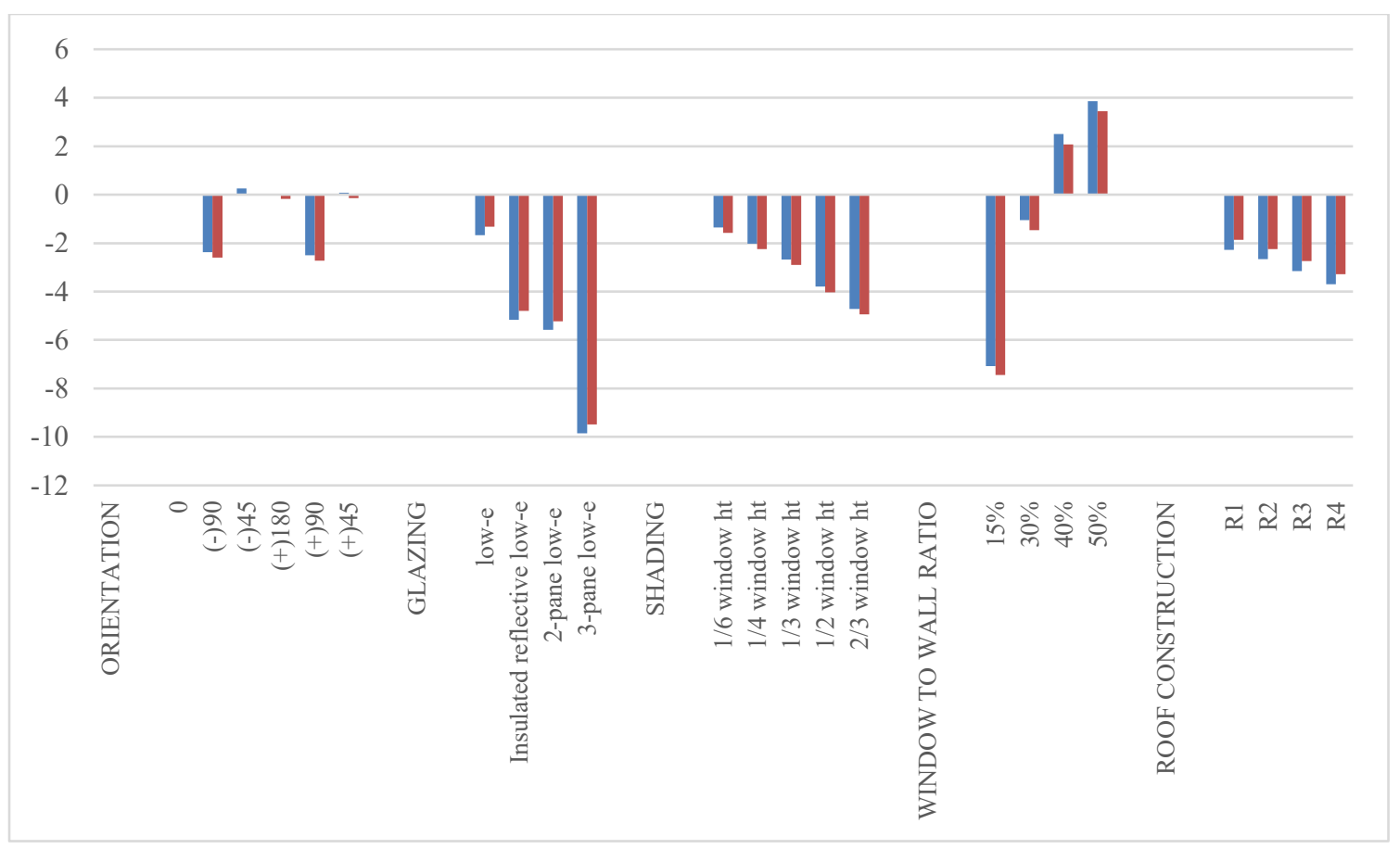

Figure 15 e-Quest vs GBS, variation in EUI, for wall assembly 4a 
The EE results that we obtained from Tally was not verified using another software, since EE calculation is much more complex when compared with $\mathrm{OE}$ calculations (Dixit, 2017). Moreover, there are several methods of calculating EE such as, process-based method, input-out based and hybrid methods. Each of these methods also use different sources of data and system boundaries (Dixit, 2017). For instance, Tally uses the $\mathrm{GaBi}$ database that is dynamically updated on the cloud based on current industry standards while Athena IE uses a custom database that is embedded within the software (the user does not have access to view the values used in EE calculation). Another reason for discrepancy of results between the two software is the method of quantity take-off. To check the accuracy of data extraction between the two software (Tally and Athena IE), the quantity take-offs were exported as excel spreadsheets. Upon comparing the data in the spreadsheets, several differences were observed between the two interfaces. This may be attributed to the difference in the level of detail extracted from Autodesk Revit model to Tally when compared with the Athena IE software (Schultz et al., 2016). 


\section{CONCLUSIONS}

This study has investigated the lifecycle energy implications of using operating energy reduction measures in commercial buildings. The extensive review of literature helped us establish a base for our study, by providing us with information regarding the various clusters of OE reduction strategies that are currently used in the building industry. This information helped us generate clusters, of study cases, that would be essential in identifying building energy trade-offs. The study has demonstrated, using a BIM enhanced approach, that simply changing the type of glazing, level of insulation (in the walls or roofs), the depth of external shades, and WWR to reduce OE demand might result in paradoxically increasing overall LCE, due to the use of additional energy-intensive material. Therefore, causing a detrimental implication on our final goal of reducing energy consumption. This study shows that design decisions need to carefully analyze and address the trade-offs from a holistic lifecycle energy perspective, that includes both EE and OE components.

The results obtained from our study show that the overall EE factor for the optimized model varies between $0.156-0.159$ in climate zone $5 \mathrm{~A}$ and $0.259-0.268$ in climate zone $2 \mathrm{~A}$ across construction assemblies. Thereby, indicating that the EE factor is influenced by the climate of a region. Conducting similar case studies, with the same system boundary in different climatic zones will help in establishing a range of values for the EE factor in each climate zone. 
Furthermore, it is important to mention that this study was conducted under various limitations. This study conducted energy simulations based upon the five broad categories, the impact of changing the glass type for the skylights and varying floor assemblies were not analyzed. The results of the study are also restricted to a specific building type, form, geographic location and climate (variations might yield different results). The study accounted only the building envelope loads (i.e. occupancy and plug loads were not considered). In addition, the study did not address the change in OE demand over the 60year lifecycle of the building. Certain inaccuracies are existent in this study, due to issues of interoperability between Autodesk Revit and Green Building Studio. Moreover, different software platforms were used to compute $\mathrm{EE}$ and $\mathrm{OE}$ requirements of the building.

An assessment of the EE implications caused by OE reducing measures, will allow decision makers to take an informed step towards reducing overall energy consumption in buildings, by taking into account the relevance of the choice of construction materials and assemblies. The results obtained from this study would assist building designers and energy consultants take much informed decisions regarding the optimization measures they choose to implement in their building design. In future, this knowledge can be used to develop a genetic algorithm that can optimize overall building LCE, based on conflicting LCE components by conducting parametric simulations. 


\section{REFERENCES}

Abanda, F. H., and Byers, L. (2016). An investigation of the impact of building orientation on energy consumption in a domestic building using emerging BIM (Building Information Modelling). Energy, 97, 517-527.

Ajayi, S. O., Oyedele, L. O., Ceranic, B., Gallanagh, M., and Kadiri, K. O. (2015). Life cycle environmental performance of material specification: a BIM-enhanced comparative assessment. International Journal of Sustainable Building Technology and Urban Development, 6(1), 14-24.

Al-Tamimi, N. A., and Fadzil, S. F. S. (2011). The potential of shading devices for temperature reduction in high-rise residential buildings in the tropics. Procedia Engineering, 21, 273-282.

ANSI/ASHRAE/IES 90.1-2016, Energy Standard for Buildings Except Low Rise Residential Buildings. American Society of Heating, Refrigerating and Air-Conditioning Engineers, Atlanta, Georgia.

Asadi, E., da Silva, M. G., Antunes, C. H., and Dias, L. (2012). A multi-objective optimization model for building retrofit strategies using TRNSYS simulations, GenOpt and MATLAB. Building and Environment, 56, 370-378.

Aste, N., Adhikari, R. S., and Buzzetti, M. (2010). Beyond the EPBD: The low energy residential settlement Borgo Solare. Applied Energy, 87(2), 629-642. 
Attia, S., Gratia, E., De Herde, A., and Hensen, J. L. (2012). Simulation-based decision support tool for early stages of zero-energy building design. Energy and buildings, 49, 215.

Bahaj, A. S., James, P. A., and Jentsch, M. F. (2008). Potential of emerging glazing technologies for highly glazed buildings in hot arid climates. Energy and Buildings, 40(5), $720-731$.

Bakar, N. N. A., Hassan, M. Y., Abdullah, H., Rahman, H. A., Abdullah, M. P., Hussin, F., and Bandi, M. (2015). Energy efficiency index as an indicator for measuring building energy performance: A review. Renewable and Sustainable Energy Reviews, 44, 1-11.

Balaras, C. A., Droutsa, K., Argiriou, A. A., and Asimakopoulos, D. N. (2000). Potential for energy conservation in apartment buildings. Energy and buildings, 31(2), 143-154.

Balouktsi, M., and Lützkendorf, T. (2016). Energy efficiency of buildings: the aspect of embodied energy. Energy Technology, 4(1), 31-43.

Basbagill, J., Flager, F., Lepech, M., and Fischer, M. (2013). Application of life-cycle assessment to early stage building design for reduced embodied environmental impacts. Building and Environment, 60, 81-92.

Bellia, L., De Falco, F., and Minichiello, F. (2013). Effects of solar shading devices on energy requirements of standalone office buildings for Italian climates. Applied Thermal Engineering, 54(1), 190-201. 
Bojic, M., Yik, F., and Leung, W. (2002). Thermal insulation of cooled spaces in high rise residential buildings in Hong Kong. Energy Conversion and Management, 43(2), 165183.

Bouchlaghem, N. (2000). Optimising the design of building envelopes for thermal performance. Automation in Construction, 10(1), 101-112.

Cabeza, L. F., Rincón, L., Vilariño, V., Pérez, G., and Castell, A. (2014). Life cycle assessment (LCA) and life cycle energy analysis (LCEA) of buildings and the building sector: A review. Renewable and sustainable energy reviews, 29, 394-416.

Caldas, L. G., and Norford, L. K. (2003). Genetic algorithms for optimization of building envelopes and the design and control of HVAC systems. Journal of solar energy engineering, 125(3), 343-351.

Castleton, H. F., Stovin, V., Beck, S. B., and Davison, J. B. (2010). Green roofs; building energy savings and the potential for retrofit. Energy and buildings, 42(10), 1582-1591.

Chan, K. T., and Chow, W. K. (1998). Energy impact of commercial-building envelopes in the sub-tropical climate. Applied Energy, 60(1), 21-39.

Chastas, P., Theodosiou, T., and Bikas, D. (2016). Embodied energy in residential buildings-towards the nearly zero energy building: A literature review. Building and Environment, 105, 267-282.

Chesné, L., Duforestel, T., Roux, J. J., and Rusaouën, G. (2012). Energy saving and 
environmental resources potentials: Toward new methods of building design. Building and Environment, 58, 199-207.

Cheung, C. K., Fuller, R. J., and Luther, M. B. (2005). Energy-efficient envelope design for high-rise apartments. Energy and buildings, 37(1), 37-48.

Christensen, C., Horowitz, S., Givler, T., Courtney, A., and Barker, G. (2005). BEopt: software for identifying optimal building designs on the path to zero net energy (No. NREL/CP-550-37733). National Renewable Energy Lab., Golden, CO (US).

Citherlet, S., and Defaux, T. (2007). Energy and environmental comparison of three variants of a family house during its whole life span. Building and Environment, 42(2), 591-598.

Coakley, D., Raftery, P., and Keane, M. (2014). A review of methods to match building energy simulation models to measured data. Renewable and sustainable energy reviews, 37, 123-141.

Çomaklı, K., and Yüksel, B. (2003). Optimum insulation thickness of external walls for energy saving. Applied thermal engineering, 23(4), 473-479.

Copiello, S. (2016). Economic implications of the energy issue: Evidence for a positive non-linear relation between embodied energy and construction cost. Energy and buildings, 123, 59-70.

Crawford, R. H., Bartak, E. L., Stephan, A., and Jensen, C. A. (2016). Evaluating the life 
cycle energy benefits of energy efficiency regulations for buildings. Renewable and Sustainable Energy Reviews, 63, 435-451.

Crawford, R. H., Czerniakowski, I., and Fuller, R. J. (2010). A comprehensive framework for assessing the life-cycle energy of building construction assemblies. Architectural science review, 53(3), 288-296.

Crawford, R., and Treloar, G. (2005, January). An assessment of the energy and water embodied in commercial building construction. In Australian Life Cycle Assessment Conference (4th: 2005: Novotel, Sydney, NSW) (pp. 1-10). Australian Life Cycle Assessment Society.

Dixit, M. K. (2017). Embodied energy and cost of building materials: correlation analysis. Building Research and Information, 45(5), 508-523.

Dixit, M. K. (2017). Life cycle embodied energy analysis of residential buildings: A review of literature to investigate embodied energy parameters. Renewable and Sustainable Energy Reviews, 79, 390-413.

Ebrahimpour, A., and Maerefat, M. (2011). Application of advanced glazing and overhangs in residential buildings. Energy Conversion and Management, 52(1), 212-219. Fay, R., Treloar, G., and Iyer-Raniga, U. (2000). Life-cycle energy analysis of buildings: a case study. Building Research and Information, 28(1), 31-41.

Gasparella, A., Pernigotto, G., Cappelletti, F., Romagnoni, P., and Baggio, P. (2011). Analysis and modelling of window and glazing systems energy performance for a well 69 
insulated residential building. Energy and Buildings, 43(4), 1030-1037.

Giordano, R., Serra, V., Tortalla, E., Valentini, V., and Aghemo, C. (2015). Embodied energy and operational energy assessment in the framework of nearly zero energy building and building energy rating. Energy Procedia, 78, 3204-3209.

Goia, F. (2016). Search for the optimal window-to-wall ratio in office buildings in different European climates and the implications on total energy saving potential. Solar Energy, 132, 467-492.

Gustavsson, L., Joelsson, A., and Sathre, R. (2010). Life cycle primary energy use and carbon emission of an eight-storey wood-framed apartment building. Energy and buildings, 42(2), 230-242.

Harkouss, F., Fardoun, F., and Biwole, P. H. (2018). Multi-objective optimization methodology for net zero energy buildings. Journal of Building Engineering, 16, 57-71.

Hassouneh, K., Alshboul, A., and Al-Salaymeh, A. (2010). Influence of windows on the energy balance of apartment buildings in Amman. Energy Conversion and Management, 51(8), 1583-1591.

Hee, W. J., Alghoul, M. A., Bakhtyar, B., Elayeb, O., Shameri, M. A., Alrubaih, M. S., and Sopian, K. (2015). The role of window glazing on daylighting and energy saving in buildings. Renewable and Sustainable Energy Reviews, 42, 323-343.

Hernandez, P., and Kenny, P. (2010). From net energy to zero energy buildings: Defining life cycle zero energy buildings (LC-ZEB). Energy and Buildings, 42(6), 815-821. 
Hernandez, P., and Kenny, P. (2011). Development of a methodology for life cycle building energy ratings. Energy policy, 39(6), 3779-3788.

Huang, Y., Niu, J. L., and Chung, T. M. (2012). Energy and carbon emission payback analysis for energy-efficient retrofitting in buildings-Overhang shading option. Energy and Buildings, 44, 94-103.

Ibn-Mohammed, T., Greenough, R., Taylor, S., Ozawa-Meida, L., and Acquaye, A. (2013). Operational vs. embodied emissions in buildings-A review of current trends. Energy and Buildings, 66, 232-245.

Jaber, S., and Ajib, S. (2011). Thermal and economic windows design for different climate zones. Energy and Buildings, 43(11), 3208-3215.

Jelle, B. P. (2011). Traditional, state-of-the-art and future thermal building insulation materials and solutions-Properties, requirements and possibilities. Energy and Buildings, 43(10), 2549-2563.

Kalogirou, S. A., and Bojic, M. (2000). Artificial neural networks for the prediction of the energy consumption of a passive solar building. Energy, 25(5), 479-491.

Kapsalaki, M., Leal, V., and Santamouris, M. (2012). A methodology for economic efficient design of Net Zero Energy Buildings. Energy and Buildings, 55, 765-778.

Karimpour, M., Belusko, M., Xing, K., and Bruno, F. (2014). Minimising the life cycle energy of buildings: Review and analysis. Building and Environment, 73, 106-114. 
Kaynakli, O. (2012). A review of the economical and optimum thermal insulation thickness for building applications. Renewable and Sustainable Energy Reviews, 16(1), 415-425.

Lam, J. C., Tsang, C. L., Li, D. H., and Cheung, S. O. (2005). Residential building envelope heat gain and cooling energy requirements. Energy, 30(7), 933-951.

Lau, A. K. K., Salleh, E., Lim, C. H., and Sulaiman, M. Y. (2016). Potential of shading devices and glazing configurations on cooling energy savings for high-rise office buildings in hot-humid climates: The case of Malaysia. International Journal of Sustainable Built Environment, 5(2), 387-399.

Leskovar, V. Ž., and Premrov, M. (2011). An approach in architectural design of energyefficient timber buildings with a focus on the optimal glazing size in the south-oriented façade. Energy and Buildings, 43(12), 3410-3418.

Li, D. H., and Wong, S. L. (2007). Daylighting and energy implications due to shading effects from nearby buildings. Applied Energy, 84(12), 1199-1209.

Li, D. H., Lam, J. C., and Wong, S. L. (2005). Daylighting and its effects on peak load determination. Energy, 30(10), 1817-1831.

Li, D. H., Yang, L., and Lam, J. C. (2013). Zero energy buildings and sustainable development implications-A review. Energy, 54, 1-10.

Li, L., Qu, M., and Peng, S. (2016). Performance evaluation of building integrated solar 
thermal shading system: Building energy consumption and daylight provision. Energy and Buildings, 113, 189-201.

Lim, Y. W., Majid, H. A., Samah, A. A., Ahmad, M. H., and Ossen, D. R. (2018). Bim and Genetic Algorithm Optimisation for Sustainable Building Envelope Design. Building Information Systems in the Construction Industry, 159.

Lollini, Barozzi, Fasano, Meroni, and Zinzi. (2006). Optimisation of opaque components of the building envelope. Energy, economic and environmental issues. Building and Environment, 41(8), 1001-1013.

Lu, Y., Wang, S., and Shan, K. (2015). Design optimization and optimal control of gridconnected and standalone nearly/net zero energy buildings. Applied Energy, 155, 463477.

Lützkendorf, T., Foliente, G., Balouktsi, M., and Wiberg, A. H. (2015). Net-zero buildings: incorporating embodied impacts. Building Research and Information, 43(1), $62-81$.

Marceau, M. L., and VanGeem, M. G. (2006). Comparison of the life cycle assessments of an insulating concrete form house and a wood frame house. Journal of ASTM International, 3(9), 1-11.

Masoso, O. T., and Grobler, L. J. (2008). A new and innovative look at anti-insulation behaviour in building energy consumption. Energy and Buildings, 40(10), 1889-1894. 
Mithraratne, N., and Vale, B. (2004). Life cycle analysis model for New Zealand houses. Building and Environment, 39(4), 483-492.

Morrissey, J., Moore, T., and Horne, R. E. (2011). Affordable passive solar design in a temperate climate: An experiment in residential building orientation. Renewable Energy, 36(2), 568-577.

Ochoa, C. E., and Capeluto, I. G. (2009). Advice tool for early design stages of intelligent facades based on energy and visual comfort approach. Energy and Buildings, 41(5), 480488.

Oral, G. K., and Yilmaz, Z. (2002). The limit U values for building envelope related to building form in temperate and cold climatic zones. Building and Environment, 37(11), 1173-1180.

Oral, G. K., Yener, A. K., and Bayazit, N. T. (2004). Building envelope design with the objective to ensure thermal, visual and acoustic comfort conditions. Building and Environment, 39(3), 281-287.

Pacheco, R., Ordóñez, J., and Martínez, G. (2012). Energy efficient design of building: A review. Renewable and Sustainable Energy Reviews, 16(6), 3559-3573.

Peippo, K., Lund, P. D., and Vartiainen, E. (1999). Multivariate optimization of design trade-offs for solar low energy buildings. Energy and Buildings, 29(2), 189-205.

Persson, M. L., Roos, A., and Wall, M. (2006). Influence of window size on the energy 
balance of low energy houses. Energy and Buildings, 38(3), 181-188.

Poirazis, H., Blomsterberg, Å., and Wall, M. (2008). Energy simulations for glazed office buildings in Sweden. Energy and Buildings, 40(7), 1161-1170.

Praseeda, K. I., Reddy, B. V., and Mani, M. (2016). Embodied and operational energy of urban residential buildings in India. Energy and Buildings, 110, 211-219.

Radhi, H. (2009). Can envelope codes reduce electricity and CO2 emissions in different types of buildings in the hot climate of Bahrain?. Energy, 34(2), 205-215.

Ramesh, T., Prakash, R., and Shukla, K. K. (2010). Life cycle energy analysis of buildings: An overview. Energy and buildings, 42(10), 1592-1600.

Ramesh, T., Prakash, R., and Shukla, K. K. (2012). Life cycle energy analysis of a residential building with different envelopes and climates in Indian context. Applied Energy, 89(1), 193-202.

Rodrigues, C., and Freire, F. (2017). Environmental impact trade-offs in building envelope retrofit strategies. The International Journal of Life Cycle Assessment, 22(4), 557-570.

Sadineni, S. B., Madala, S., and Boehm, R. F. (2011). Passive building energy savings: A review of building envelope components. Renewable and Sustainable Energy Reviews, 15(8), 3617-3631.

Santos, P., Martins, R., Gervásio, H., and da Silva, L. S. (2014). Assessment of building operational energy at early stages of design-A monthly quasi-steady-state 
approach. Energy and Buildings, 79, 58-73.

Sartori, I., and Hestnes, A. G. (2007). Energy use in the life cycle of conventional and low-energy buildings: A review article. Energy and buildings, 39(3), 249-257.

Sartori, I., Napolitano, A., and Voss, K. (2012). Net zero energy buildings: A consistent definition framework. Energy and buildings, 48, 220-232.

Scheuer, C., Keoleian, G. A., and Reppe, P. (2003). Life cycle energy and environmental performance of a new university building: modeling challenges and design implications. Energy and buildings, 35(10), 1049-1064.

Schultz, J., Ku, K., Gindlesparger, M., and Doerfler, J. (2016). A benchmark study of BIM-based whole-building life-cycle assessment tools and processes. International Journal of Sustainable Building Technology and Urban Development, 7(3-4), 219-229.

Scofield, J. H. (2002). Early performance of a green academic building. TransactionsAmerican Society of Heating Refrigerating and Air Conditioning Engineers, 108(2), $1214-1232$.

Shameri, M. A., Alghoul, M. A., Sopian, K., Zain, M. F. M., and Elayeb, O. (2011). Perspectives of double skin façade systems in buildings and energy saving. Renewable and Sustainable Energy Reviews, 15(3), 1468-1475.

Shi, X. (2011). Design optimization of insulation usage and space conditioning load using energy simulation and genetic algorithm. Energy, 36(3), 1659-1667. 
Shrivastava, S., and Chini, A. (2012). Using building information modeling to assess the initial embodied energy of a building. International Journal of Construction Management, 12(1), 51-63.

Singh, M. C., and Garg, S. N. (2009). Energy rating of different glazing Indian climates. Energy, 34(11), 1986-1992.

Sozer, H. (2010). Improving energy efficiency through the design of the building envelope. Building and environment, 45(12), 2581-2593.

Stevanović, S. (2013). Optimization of passive solar design strategies: A review. Renewable and Sustainable Energy Reviews, 25, 177-196.

Susorova, I., Tabibzadeh, M., Rahman, A., Clack, H. L., and Elnimeiri, M. (2013). The effect of geometry factors on fenestration energy performance and energy savings in office buildings. Energy and Buildings, 57, 6-13.

Thormark, C. (2002). A low energy building in a life cycle—its embodied energy, energy need for operation and recycling potential. Building and environment, 37(4), 429-435.

Treloar, G. J. (1997). Extracting embodied energy paths from input-output tables: towards an input-output-based hybrid energy analysis method. Economic Systems Research, 9(4), 375-391.

Utama, A., and Gheewala, S. H. (2009). Indonesian residential high rise buildings: A life cycle energy assessment. Energy and Buildings, 41(11), 1263-1268. 
Wang, L., Nyuk, H. W., and Li, S. (2007). Facade design optimization for naturally ventilated residential buildings in Singapore. Energy and Buildings, 39(8), 954-961.

Wang, W., Rivard, H., and Zmeureanu, R. (2005). An object-oriented framework for simulation-based green building design optimization with genetic algorithms. Advanced Engineering Informatics, 19(1), 5-23.

Wilde, P., Tian, W., and Augenbroe, G. (2011). Longitudinal prediction of the operational energy use of buildings. Building and Environment, 46(8), 1670-1680.

Xing, S., Xu, Z., and Jun, G. (2008). Inventory analysis of LCA on steel-and concreteconstruction office buildings. Energy and Buildings, 40(7), 1188-1193.

Y. G., and Norton, B. (2002). Life-cycle operational and embodied energy for a generic single-storey office building in the UK. Energy, 27(1), 77-92.

Yin, R., Xu, P., and Shen, P. (2012). Case study: Energy savings from solar window film in two commercial buildings in Shanghai. Energy and Buildings, 45, 132-140.

Yu, J., Yang, C., and Tian, L. (2008). Low-energy envelope design of residential building in hot summer and cold winter zone in China. Energy and Buildings, 40(8), 1536-1546.

Zemella, G., De March, D., Borrotti, M., and Poli, I. (2011). Optimised design of energy efficient building façades via Evolutionary Neural Networks. Energy and Buildings, 43(12), 3297-3302.

Zeng, R., and Chini, A. (2017). A review of research on embodied energy of buildings 
using bibliometric analysis. Energy and Buildings.

Zhang, T., Tan, Y., Yang, H., and Zhang, X. (2016). The application of air layers in building envelopes: A review. Applied energy, 165, 707-734.

Zhou, Z., Feng, L., Zhang, S., Wang, C., Chen, G., Du, T., ... and Zuo, J. (2016). The operational performance of "net zero energy building": A study in China. Applied energy, 177, 716-728.

Zhu, J., Chew, D. A., Lv, S., and Wu, W. (2013). Optimization method for building envelope design to minimize carbon emissions of building operational energy consumption using orthogonal experimental design (OED). Habitat International, 37, $148-154$.

Zinzi, M., Carnielo, E., and Agnoli, S. (2012). Characterization and assessment of cool coloured solar protection devices for Mediterranean residential buildings application. Energy and buildings, 50, 111-119

Zuo, J., Pullen, S., Rameezdeen, R., Bennetts, H., Wang, Y., Mao, G., ... and Duan, H. (2017). Green building evaluation from a life-cycle perspective in Australia: A critical review. Renewable and Sustainable Energy Reviews, 70, 358-368. 


\section{APPENDIX A}

\section{WALL ASSEMBLY DETAILS}

\begin{tabular}{|c|c|c|c|c|c|c|c|}
\hline \multicolumn{4}{|c|}{$\begin{array}{c}\text { ASHRAE PRESCRIPTIVE CODE FOR } \\
\text { WALLS IN CLIMATE ZONE } 2 \text { A } \\
\text { WALL: Umax assembly }=0.089 ; \text { Insulation } \text { Rmin=13 } \\
\text { ROOF: Umax assembly }=0.039 ; \text { Insulation } \text { Rmin=25 }\end{array}$} & \multicolumn{4}{|c|}{$\begin{array}{c}\text { ASHRAE PRESCRIPTIVE CODE FOR } \\
\text { WALLS IN CLIMATE ZONE 5A } \\
\text { WALL: Umax assembly }=\mathbf{0 . 0 5 5} \text {; Insulation } \text { Rmin }=13+10 \text { c.i. } \\
\text { ROOF: Umax assembly }=\mathbf{0 . 0 3 2} \text {; Insulation } \text { Rmin }=30\end{array}$} \\
\hline \multicolumn{4}{|c|}{ ASHRAE 90.1-2016 benchmark } & \multicolumn{4}{|c|}{ ASHRAE 90.1-2016 benchmark } \\
\hline Wall: $\mathrm{U}=.075$ & $\begin{array}{c}\text { R- } \\
\text { value/inch }\end{array}$ & $\begin{array}{l}\text { thickness } \\
\text { (in) }\end{array}$ & $\begin{array}{c}\text { R- } \\
\text { value }\end{array}$ & Wall: $\mathrm{U}=. \mathbf{0 5 1}$ & $\begin{array}{c}\text { R- } \\
\text { value/inch }\end{array}$ & $\begin{array}{l}\text { thickne } \\
\text { ss (in) }\end{array}$ & $\begin{array}{c}\text { R- } \\
\text { value }\end{array}$ \\
\hline Exterior Air film & 0.17 & 1 & 0.17 & Exterior Air film & 0.17 & 1 & 0.17 \\
\hline Stucco & 0.2 & 4 & 0.8 & Stucco & 0.2 & 4 & 0.8 \\
\hline Sheathing & 0.56 & $5 / 8^{\prime \prime}$ & 0.56 & Sheathing & 0.56 & $5 / 8 "$ & 0.56 \\
\hline Effective framing for R-13 & 1.714 & 3.5 & 6 & Effective framing for R-13 & 1.714 & 3.5 & 6 \\
\hline Fiberglass Batt & 3 & 1.5 & 4.5 & Fiberglass Batt & 3 & 3.5 & 10.5 \\
\hline Drywall/ gypsum board & 0.56 & $5 / 8^{\prime \prime}$ & 0.56 & Drywall/ gypsum board & 0.56 & $5 / 8^{\prime \prime}$ & 0.56 \\
\hline Interior Air film & 0.68 & 1 & 0.68 & Interior Air film & 0.68 & 1 & 0.68 \\
\hline TOTAL & & & 13.27 & TOTAL & & & 19.27 \\
\hline \multicolumn{4}{|c|}{ Wall assembly $1 \mathrm{a}$} & \multicolumn{4}{|c|}{ Wall assembly $1 \mathrm{~b}$} \\
\hline Wall: $\mathrm{U}=.066$ & $\begin{array}{c}\text { R- } \\
\text { value/inch }\end{array}$ & $\begin{array}{l}\text { thickness } \\
\text { (in) }\end{array}$ & $\begin{array}{c}\text { R- } \\
\text { value }\end{array}$ & Wall: $U=.04$ & $\begin{array}{c}\text { R- } \\
\text { value/inch }\end{array}$ & $\begin{array}{l}\text { thickne } \\
\text { ss (in) }\end{array}$ & $\begin{array}{c}\text { R- } \\
\text { value }\end{array}$ \\
\hline Exterior Air film & 0.17 & 1 & 0.17 & Exterior Air film & 0.17 & 1 & 0.17 \\
\hline Brick & 0.2 & 4 & 0.8 & Brick & 0.2 & 4 & 0.8 \\
\hline Sheathing & 0.56 & $5 / 8^{\prime \prime}$ & 0.56 & Sheathing & 0.56 & $5 / 8^{\prime \prime}$ & 0.56 \\
\hline Effective framing for R-13 & 1.714 & 3.5 & 6 & Effective framing for R-13 & 1.714 & 3.5 & 6 \\
\hline Mineral wool & 3.12 & 2 & 6.24 & Cellulose Insulation & 4 & 4 & 16 \\
\hline Drywall/ gypsum board- & 0.56 & $5 / 8^{\prime \prime}$ & 0.56 & Drywall/gypsum board & 0.56 & $5 / 8^{\prime \prime}$ & 0.56 \\
\hline Interior Air film & 0.68 & 1 & 0.68 & Interior Air film & 0.68 & 1 & 0.68 \\
\hline TOTAL & & & 15.01 & TOTAL & & & 24.77 \\
\hline \multicolumn{4}{|c|}{ Wall assembly 2 a } & \multicolumn{4}{|c|}{ Wall assembly 2 b } \\
\hline Wall: $\mathrm{U}=.052$ & $\begin{array}{c}\text { R- } \\
\text { value/inch }\end{array}$ & $\begin{array}{l}\text { thickness } \\
\text { (in) }\end{array}$ & $\begin{array}{c}\text { R- } \\
\text { value }\end{array}$ & Wall: $\mathrm{U}=. \mathbf{0 3 9}$ & $\begin{array}{c}\text { R- } \\
\text { value/inch }\end{array}$ & $\begin{array}{l}\text { thickne } \\
\text { ss (in) }\end{array}$ & $\begin{array}{c}\text { R- } \\
\text { value }\end{array}$ \\
\hline Exterior Air film & 0.17 & 1 & 0.17 & Exterior Air film & 0.17 & 1 & 0.17 \\
\hline Concrete panels & 0.08 & 2 & 0.16 & Brick & 0.2 & 4 & 0.8 \\
\hline Sheathing & 0.56 & $5 / 8^{\prime \prime}$ & 0.56 & Sheathing & 0.56 & $5 / 8^{\prime \prime}$ & 0.56 \\
\hline Effective framing for R-13 & 1.714 & 3.5 & 6 & Effective framing for R-13 & 1.714 & 3.5 & 6 \\
\hline Mineral wool & 3.12 & 3.5 & 10.92 & Extruded polystyrene & 5.5 & 3 & 16.5 \\
\hline Drywall/ gypsum board & 0.56 & $5 / 8^{\prime \prime}$ & 0.56 & Drywall/ gypsum board & 0.56 & $5 / 8^{\prime \prime}$ & 0.56 \\
\hline Interior Air film & 0.68 & 1 & 0.68 & Interior Air film & 0.68 & 1 & 0.68 \\
\hline TOTAL & & & 19.05 & TOTAL & & & 25.27 \\
\hline \multicolumn{4}{|c|}{ Wall assembly $3 a$} & \multicolumn{4}{|c|}{ Wall assembly $3 \mathbf{b}$} \\
\hline Wall: $U=.047$ & $\begin{array}{c}\text { R- } \\
\text { value/inch }\end{array}$ & $\begin{array}{l}\text { thickness } \\
\text { (in) }\end{array}$ & $\begin{array}{c}\text { R- } \\
\text { value }\end{array}$ & Wall: $U=.036$ & $\begin{array}{c}\text { R- } \\
\text { value/inch }\end{array}$ & $\begin{array}{l}\text { thickne } \\
\text { ss (in) }\end{array}$ & $\begin{array}{c}\text { R- } \\
\text { value }\end{array}$ \\
\hline Exterior Air film & 0.17 & 1 & 0.17 & Exterior Air film & 0.17 & 1 & 0.17 \\
\hline Concrete panels & 0.08 & 2 & 0.16 & Stone veneer (limestone) & 0.114 & 4 & 0.456 \\
\hline Sheathing & 0.56 & $5 / 8^{\prime \prime}$ & 0.56 & Sheathing & 0.56 & $5 / 8^{\prime \prime}$ & 0.56 \\
\hline Effective framing for R-13 & 1.714 & 3.5 & 6 & Effective framing for R-13 & 1.714 & 3.5 & 6 \\
\hline Expanded polystyrene & 3.7 & 3.5 & 12.95 & Extruded polystyrene & 5.5 & 3.5 & 19.25 \\
\hline Drywall/ gypsum board & 0.56 & $5 / 8^{\prime \prime}$ & 0.56 & Drywall/ gypsum board & 0.56 & $5 / 8^{\prime \prime}$ & 0.56 \\
\hline Interior Air film & 0.68 & 1 & 0.68 & Interior Air film & 0.68 & 1 & 0.68 \\
\hline TOTAL & & & 21.08 & TOTAL & & & 27.676 \\
\hline
\end{tabular}




\begin{tabular}{|l|c|c|c|l|c|c|c|}
\hline \multicolumn{4}{|c|}{ Wall assembly 4a } & \multicolumn{4}{c|}{ Wall assembly 4b } \\
\hline Wall: U=.037 & $\begin{array}{c}\text { R- } \\
\text { value/inch }\end{array}$ & $\begin{array}{c}\text { thickness } \\
\text { (in) }\end{array}$ & $\begin{array}{c}\text { R- } \\
\text { value }\end{array}$ & Wall: U=.033 & $\begin{array}{c}\text { R- } \\
\text { value/inch }\end{array}$ & $\begin{array}{c}\text { thickne } \\
\text { ss (in) }\end{array}$ & $\begin{array}{c}\text { R- } \\
\text { value }\end{array}$ \\
\hline Exterior Air film & 0.17 & 1 & 0.17 & Exterior Air film & 0.17 & 1 & 0.17 \\
\hline Stone veneer (limestone) & 0.114 & 4 & 0.456 & Stone veneer (limestone) & 0.114 & 4 & 0.456 \\
\hline Sheathing & 0.56 & $5 / 8 "$ & 0.56 & Sheathing & 0.56 & $5 / 8^{\prime \prime}$ & 0.56 \\
\hline Effective framing for R-13 & 1.714 & 3.5 & 6 & Effective framing for R-13 & 1.714 & 3.5 & 6 \\
\hline High density fiberglass batt & 3.6 & 3.5 & 12.6 & High density fiberglass batt & 3.55 & 3.5 & 12.425 \\
\hline Polyurethane insulation & 6 & 1 & 6 & Polyurethane insulation & 6.1 & 1.5 & 9.15 \\
\hline Drywall/ gypsum board- & 0.56 & $5 / 8 "$ & 0.56 & Drywall/ gypsum board & 0.56 & $5 / 8^{\prime \prime}$ & 0.56 \\
\hline Interior Air film & 0.68 & 1 & 0.68 & Interior Air film & 0.68 & 1 & 0.68 \\
\hline TOTAL & & & 27.026 & TOTAL & & & 30.001 \\
\hline
\end{tabular}




\section{APPENDIX B}

ROOF ASSEMBLY DETAILS

\begin{tabular}{|c|c|c|c|c|c|c|c|}
\hline \multicolumn{8}{|c|}{$\begin{array}{l}\text { ASHRAE PRESCRIPTIVE CODE FOR ROOFS IN CLIMATE ZONE 2A and 5A } \\
\text { ROOF: Umax assembly }=0.039 \text {; Insulation Rmin }=25 \\
\text { ROOF: Umax assembly }=0.032 ; \text { Insulation } R \min =30\end{array}$} \\
\hline \multicolumn{4}{|c|}{ Roof assembly Q1 } & \multicolumn{4}{|c|}{ Roof assembly Q3 } \\
\hline Roof: $\mathrm{U}=. \mathbf{0 3 4}$ & $\begin{array}{l}\text { R- } \\
\text { value/inch }\end{array}$ & $\begin{array}{l}\text { thickness } \\
\text { (in) }\end{array}$ & $\begin{array}{l}\text { R- } \\
\text { value }\end{array}$ & Roof: $\mathrm{U}=. \mathbf{0 3 1}$ & $\begin{array}{l}\text { R- } \\
\text { value/inch }\end{array}$ & $\begin{array}{l}\text { thickness } \\
\text { (in) }\end{array}$ & $\begin{array}{l}R- \\
\text { value }\end{array}$ \\
\hline Exterior Air film & 0.17 & 1 & 0.17 & Exterior Air film & 0.17 & 1 & 0.17 \\
\hline Roofing membrane & & & & Roofing membrane & & & \\
\hline Roof board & 0.45 & $5 / 8 "$ & 0.45 & Roof board & 0.45 & $5 / 8 "$ & 0.45 \\
\hline EPS insulation & 3.95 & 7 & 27.65 & Rigid foam insulation & 5.51 & 5.5 & 30.30 \\
\hline Sheathing & 0.45 & $5 / 8 "$ & 0.45 & Sheathing & 0.45 & $5 / 8 "$ & 0.45 \\
\hline Vapor barrier & & & & Vapor barrier & & & \\
\hline Steel deck & 0 & 0 & 0 & Steel deck & 0 & 0 & 0 \\
\hline Interior Air film & 0.68 & 1 & 0.68 & Interior Air film & 0.68 & 1 & 0.68 \\
\hline TOTAL & & 9 & 29.4 & TOTAL & & 7.5 & 32.055 \\
\hline \multicolumn{4}{|c|}{ Roof assembly Q2 } & \multicolumn{4}{|c|}{ Roof assembly Q4 } \\
\hline Roof: $\mathrm{U}=. \mathbf{0 3 3 1}$ & $\begin{array}{l}\text { R- } \\
\text { value/inch }\end{array}$ & $\begin{array}{l}\text { thickness } \\
\text { (in) }\end{array}$ & $\begin{array}{l}\text { R- } \\
\text { value }\end{array}$ & Roof: $\mathrm{U}=.022$ & $\begin{array}{l}\text { R- } \\
\text { value/inch }\end{array}$ & $\begin{array}{l}\text { thickness } \\
\text { (in) }\end{array}$ & $\begin{array}{l}\text { R- } \\
\text { value }\end{array}$ \\
\hline Exterior Air film & 0.17 & 1 & 0.17 & Exterior Air film & 0.17 & 1 & 0.17 \\
\hline Roofing tiles & 0.44 & 2 & 0.88 & Roofing tiles & 0.44 & 2 & 0.88 \\
\hline Roofing membrane & & & & Roof board & 0.45 & $5 / 8 "$ & 0.45 \\
\hline Roof board & 0.45 & $5 / 8 "$ & 0.45 & Fiberglass batt insulation & 3.2 & 1 & 3.2 \\
\hline XPS insulation & 5.5 & 5 & 27.5 & Polyurethane board & 6.6 & 6 & 39.6 \\
\hline Sheathing & 0.45 & $5 / 8 "$ & 0.45 & Sheathing & 0.45 & $5 / 8 "$ & 0.45 \\
\hline Vapor barrier & & & & Vapor barrier & & & \\
\hline Steel deck & 0 & 0 & 0 & Steel deck & 0 & 0 & 0 \\
\hline Interior Air film & 0.68 & 1 & 0.68 & Interior Air film & 0.68 & 1 & 0.68 \\
\hline TOTAL & & 9 & 30.13 & TOTAL & & 11 & 45.43 \\
\hline
\end{tabular}

